\title{
A review of the gravity and magnetic studies in the Tyrrhenian Basin and its volcanic districts
}

\author{
Federico Cella $\left({ }^{2}\right)$, Maurizio Fedi $\left({ }^{1}\right)$, Giovanni Florio $\left({ }^{1}\right)$, Valeria Paoletti $\left({ }^{3}\right)$ and Antonio Rapolla $\left({ }^{1}\right)\left({ }^{3}\right)$ \\ (') Dipartimento di Scienze della Terra, Università degli Studi di Napoli «Federico II», Napoli, Italy \\ $\left(^{2}\right)$ Dipartimento di Scienze della Terra, Università degli Studi della Calabria, Arcavacata di Rende (CS), Italy \\ (3) C.U.G.RI., Università degli Studi di Napoli «Federico II»/Università degli Studi di Salerno, Fisciano (SA), Italy
}

\begin{abstract}
Since the Sixties, the turning point marked by the Plate Tectonics global theory has provided new ideas for the interpretation of the complex geodynamic evolution of the Mediterranean area. The renewed interest that followed gave a strong impulse to the geological and geophysical investigations of the Mediterranean area and, more specifically, of the Tyrrhenian Basin. Therefore, large scale geophysical surveys and oceanographic cruises were carried out until the end of the Eighties to fill the gap of geophysical information existing in the area until then. Afterwards, short scale surveys were prevalent to improve the detail of the information in areas of geodynamic interest. The gathered data sets allowed new models to be formulated, improving the knowledge of the crustal and lithospheric structure of the Tyrrhenian Basin (and surrounding areas) and the reconstruction of its complex geodynamic evolution. In this frame, the contribution of gravity and magnetic investigations has been unquestionable and deserves a wide-ranging review both on large and small scale. The main features of the potential fields resulting from these surveys will be described and the interpretative models suggested by several authors will be summarized.
\end{abstract}

Key words Tyrrhenian Basin - gravity anomaly field - magnetic anomaly field - enhancing techniques - 2D/3D data inversion

\section{The gravity field of the Tyrrhenian Basin}

\subsection{Gravity surveys}

\subsubsection{Regional Surveys}

Significant gravity data were collected by the Osservatorio Geofisico Sperimentale (OGS)

Mailing address: Dr. Federico Cella, Dipartimento di Scienze della Terra, Università degli Studi di Napoli «Federico II», Largo San Marcellino 10, 80138 Napoli, Italy; e-mail: f.cella@unical.it including also the Tyrrhenian Sea (Gantar et al., 1968; Morelli et al., 1975a,b). Because of the smaller track spacing $(\approx 3 \mathrm{~km})$, measurements covering the Tyrrhenian Sea proved more accurate $( \pm 3 \mathrm{mGal})$ than the rest of the data set (free air data correction based on the Geodetic Reference System 1967; density for terrain correction: $2.67 \mathrm{~g} / \mathrm{cm}^{3}$ ). The results concerning the Tyrrhenian Basin (Morelli, 1970) still represent the only base for a complete and reasonably detailed free air and Bouguer anomaly map of the whole area. Before these surveys, only one cruise provided gravity data along a single track from Corsica to Naples (USGS, 1965).

No major large scale surveys were subsequently carried out in the area. Other gravity maps of the Tyrrhenian Basin were published (Bureau Gravimetrique International, 1971; Ogniben et al., 1975; Morelli and Val'chuk, 1988; Makris et al., 1998), but all at a lower detail. 
Further gravity data concerning the Tyr-rhenian Basin have been provided, but only at a local scale, covering small peripheral sectors of the Basin and including some coastal areas or some islands located at its eastern and southern sides.

A survey was conducted on the Eolian Arc in 1983 and 1985 by the AGIP-ENEL-EMS Joint venture including main and transverse lines spaced 1 and $3 \mathrm{~km}$, respectively. In addition two ground surveys (222 stations) were carried out on the Islands of Salina, Vulcano and Lipari.

Other local gravity surveys were carried out on the Elba Island (Bozzo et al., 1984; Cassano et al., 2001), Tuscan Islands (Bonasia, unumpublished data) and Ponza (Bellucci et al., 1997) but they were strictly limited to ground measurements.

Finally, the Gulf of Naples was surveyed during five cruises by means of sea bottom gravity measurements (Berrino et al., 1998) made on a 0.5 mile square grid at depths ranging from 10 to $400 \mathrm{~m}$.

\subsection{Description of the gravity anomaly field}

The first measurements carried out within the Tyrrhenian basin revealed a gravity field roughly correlated with the main regional morphological features and dominated by a long wavelength, very high amplitude positive anomaly $(+250 \mathrm{mGal})$ centred on the bathyal plain of the basin (fig. 1). This is comparable to other regional positive anomalies of the Mediterranean Basin like the Jonian Basin and the Ligurian-Provençal Basin. This anomaly is encircled by long period negative anomalies located in all the surrounding continental regions (i.e. Appenine thrust/fold belt system, north-

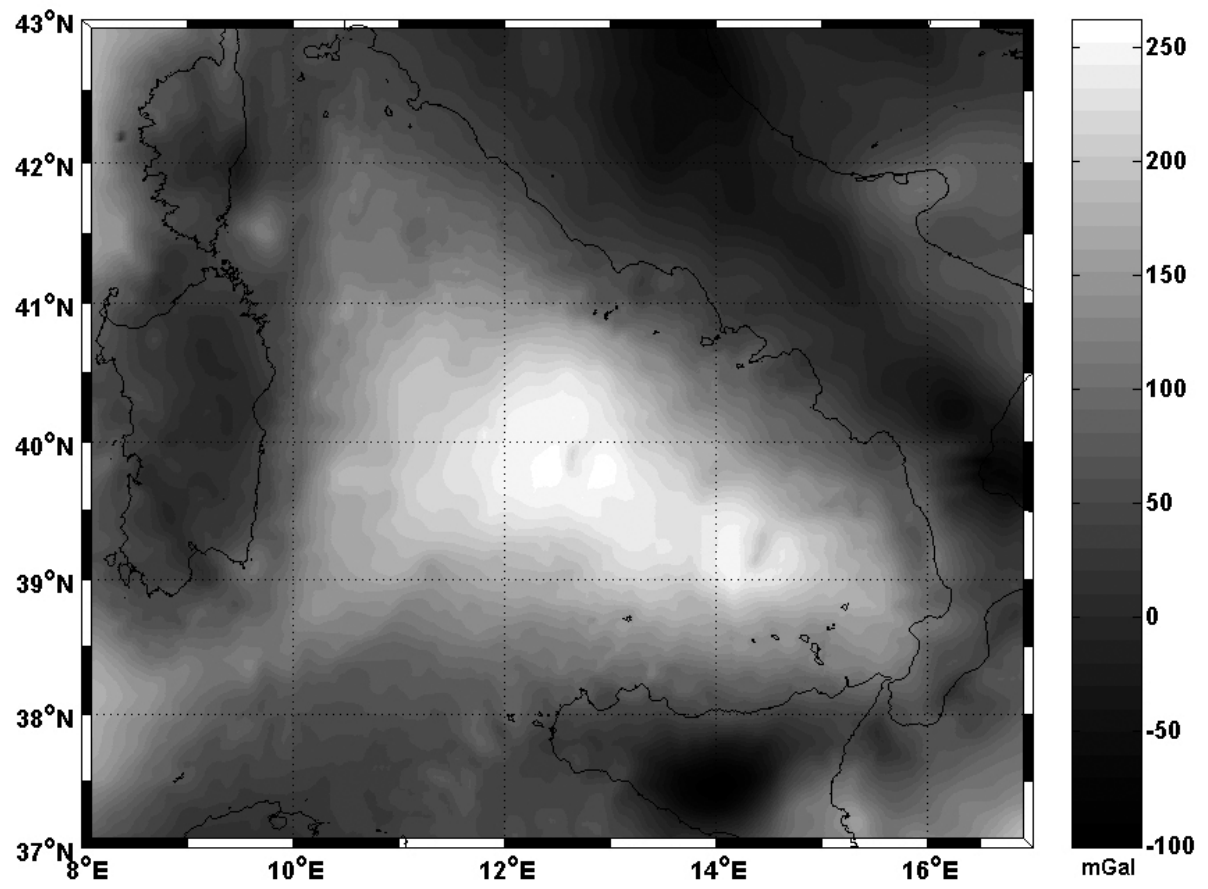

Fig. 1. Bouguer gravity anomaly map of the Tyrrhenian Basin; reference system IGSN-71; Bouguer density = $2.67 \mathrm{~g} / \mathrm{cm}^{3} ; 1967$ Normal Gravity Formula. 


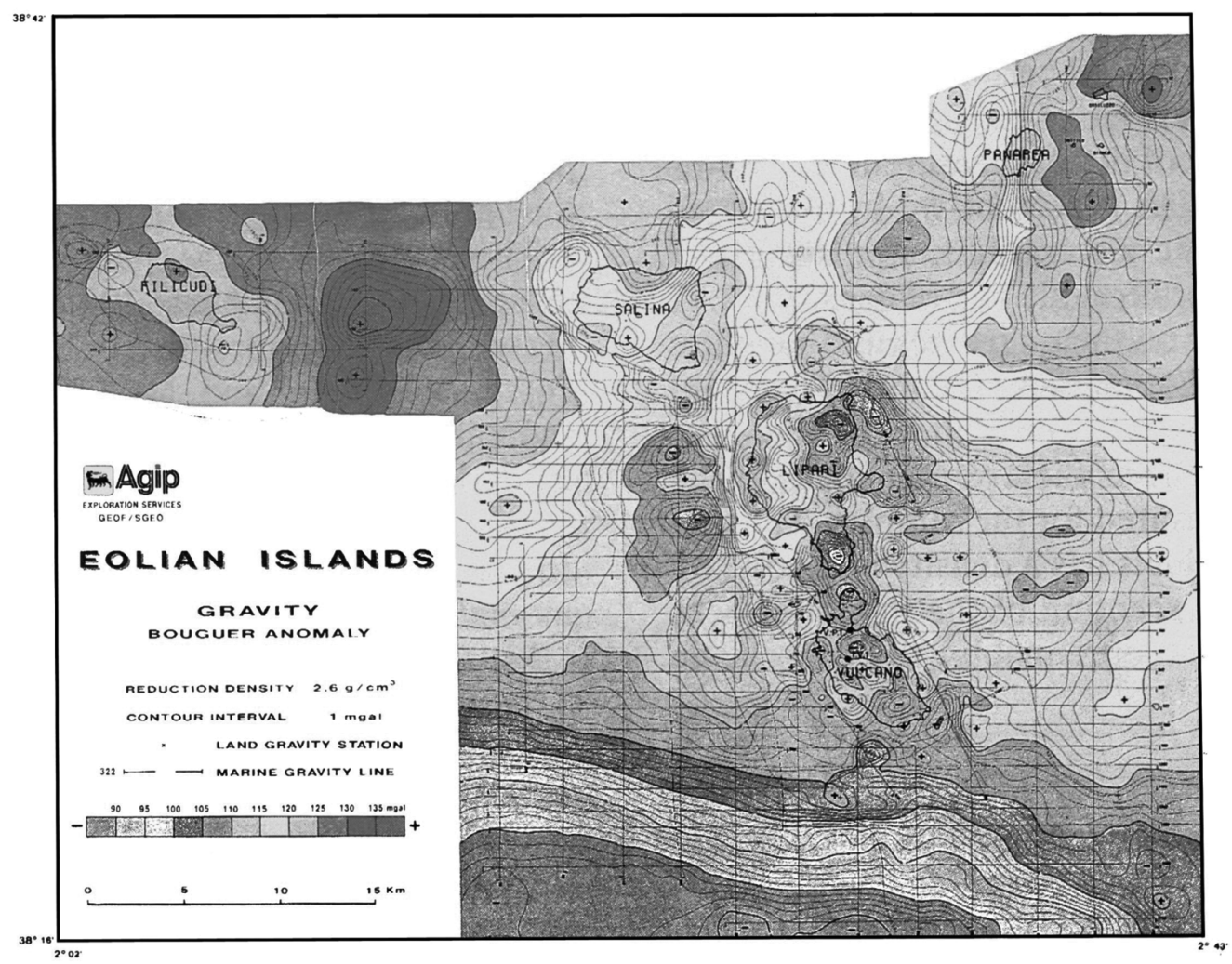

Fig. 2. Bouguer gravity anomaly map of the Eolian Islands (Modified from Barberi et al., 1994).

ward and eastward; Sicily, southward; SardiniaCorsica microplate, westward).

The analysis of the Bouguer Anomaly Map of the Tyrrhenian Basin reveals the existence of two distinct short period maxima located within the regional anomaly. The first is located to the eastern end of the bathyal plain and includes the Marsili Seamount zone. On the western side, another maximum area is visible immediately west of the Vavilov Seamount. These two sectors roughly mark the western and eastern boundaries of the area partially floored by basaltic magmas (Duschenes et al., 1986). Many small period anomalies are located along the peri-tyrrhenian borders of the basin and around the central regional maximum.

The western side of the positive regional anomaly is interrupted by weak short period anomalies correlated to submarine (Baronie Seamounts) asymmetrical, tilted basement blocks (Kastens et al., 1988). They formed by stretching, thinning of the continental crust and by rotational normal faulting (Rehault et al., 1987) before the basaltic volcanism. Northward, a circular positive anomaly is visible SE of Corsica and is not correlated with the seafloor morphology. Above $41^{\circ} \mathrm{N}$, the northern flank of the regional anomaly appears indented by small anomalies most of which are correlated with igneous intrusions resulting from tectonic phases and anatectic magmatism. Several short period anomalies are also visible along the eastern and southern flanks. They are associated with volcanic islands and seamounts representative of the most recent phases of calc-alkaline arc magmatism, trending from NW (older terms) to SE 


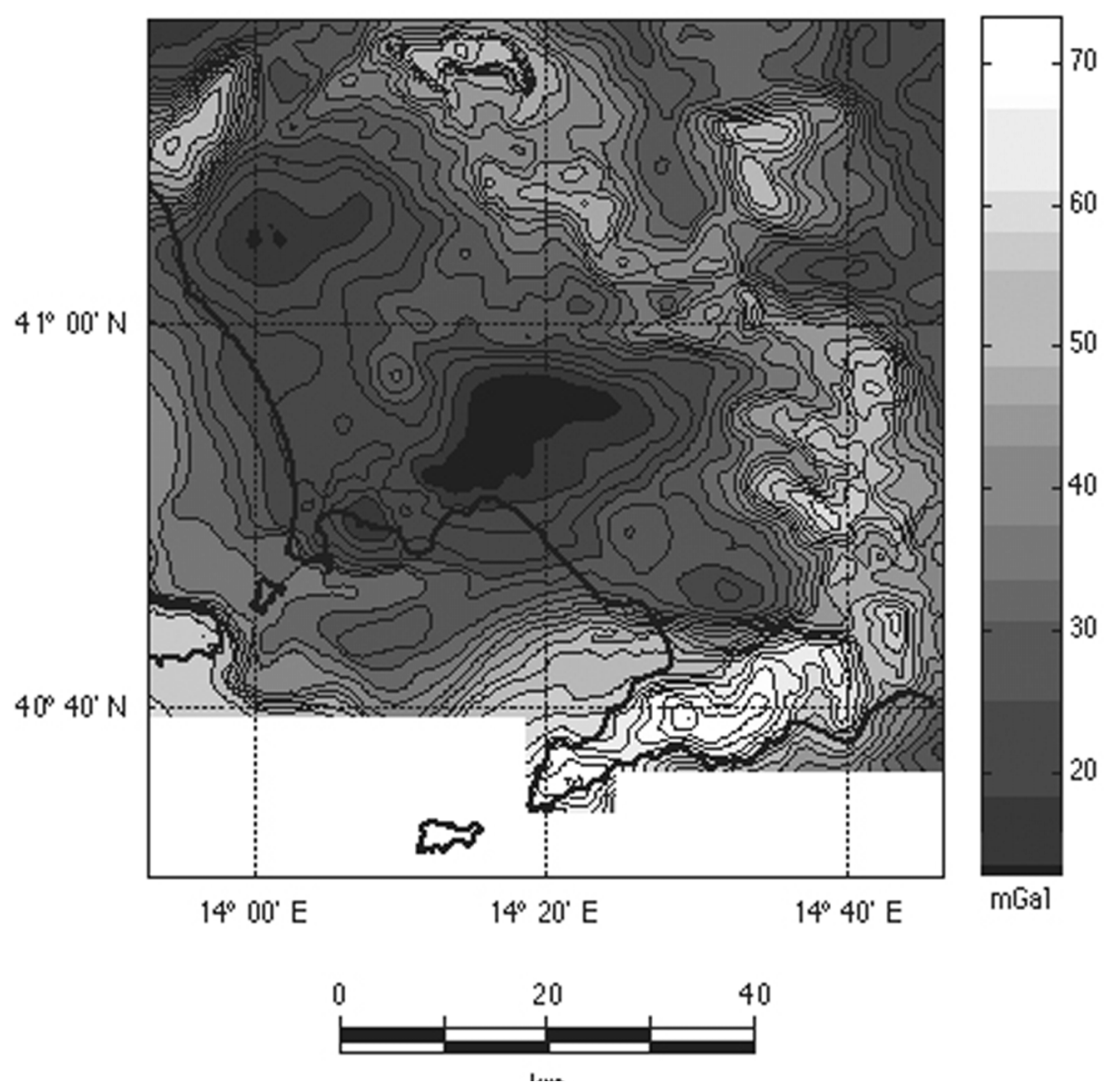

Fig. 3. Gravity map of Campanian Plain, obtained by merging the onshore Bouguer anomaly map (Cassano and La Torre, 1987) with the offshore data of the Gulf of Naples and Pozzuoli (Berrino et al., 1998). Contour interval: 3 mGal. (modified from Cella et al., 2007).

(younger terms). A significant example is represented by the Aeolian Islands, where two strong positive anomalies are visible between Salina and Filicudi and between Panarea and Stromboli respectively (fig. 2). A negative anomaly is visible in the southern sector of this area and is partially correlated to the Cefalù Basin.

Eastward, the Bouguer anomaly field surveyed in the Gulf of Naples by Berrino et al. (1998) shows a gravity gradient running roughly along a N-S direction, interrupted by a negative anomaly located south of the Gulf of Pozzuoli, whereas strong gradients border the Islands of Ischia and Procida (fig. 3).

\subsection{Data interpretation and gravity modelling}

\subsubsection{Data interpretation at regional scale}

Even prior to results from the first seismic investigations surveyed in the area, Morelli (1970) recognized the strong regional positive anomaly centered on the bathyal plain as the consequence of a mantle rise, ascribing the weak positive free air anomalies to the absence of isostatic equilibrium and to an active subsidence. Strong positive free air anomalies were detected of the main submarine reliefs and indicated a local isostatic adjustment. The negative 


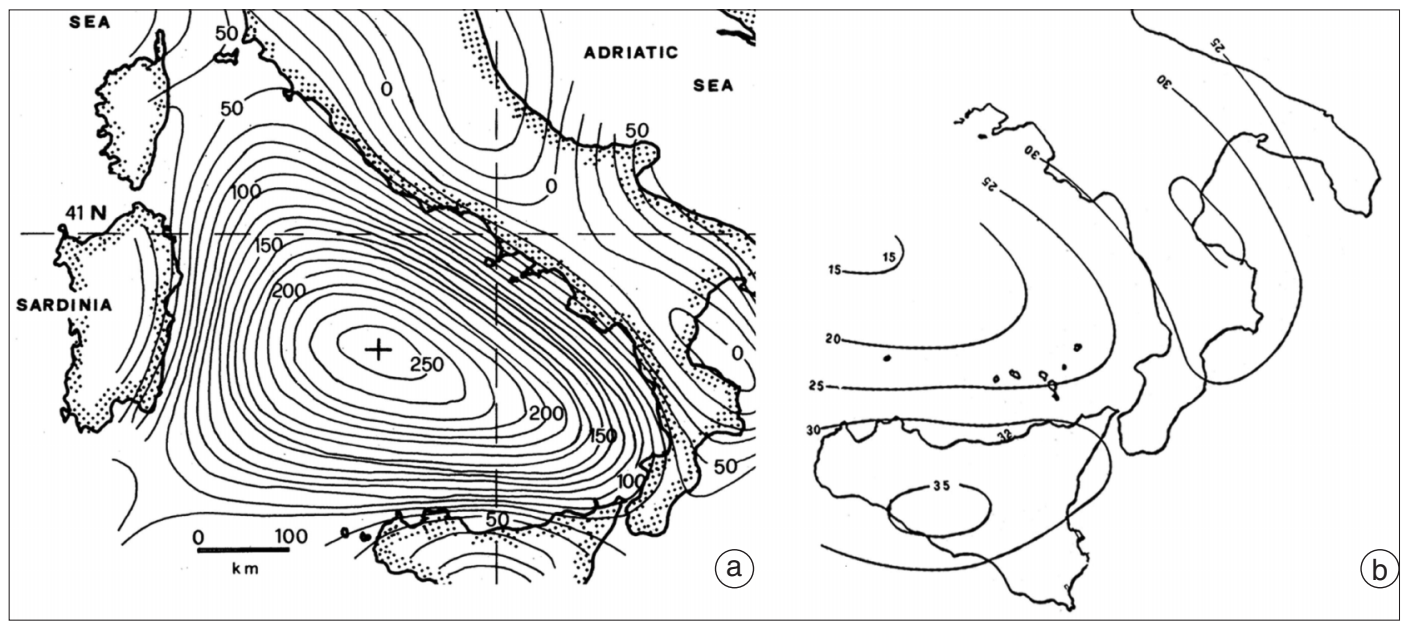

Fig. 4a,b. a) Long wavelength component of the gravity anomaly field (low-pass filter: $\lambda>215 \mathrm{~km}$ ). Modified from Corrado and Rapolla (1981); b) Moho bathymetry in the Eastern Tyrrhenian area. Modified from Pinna and Rapolla (1979).
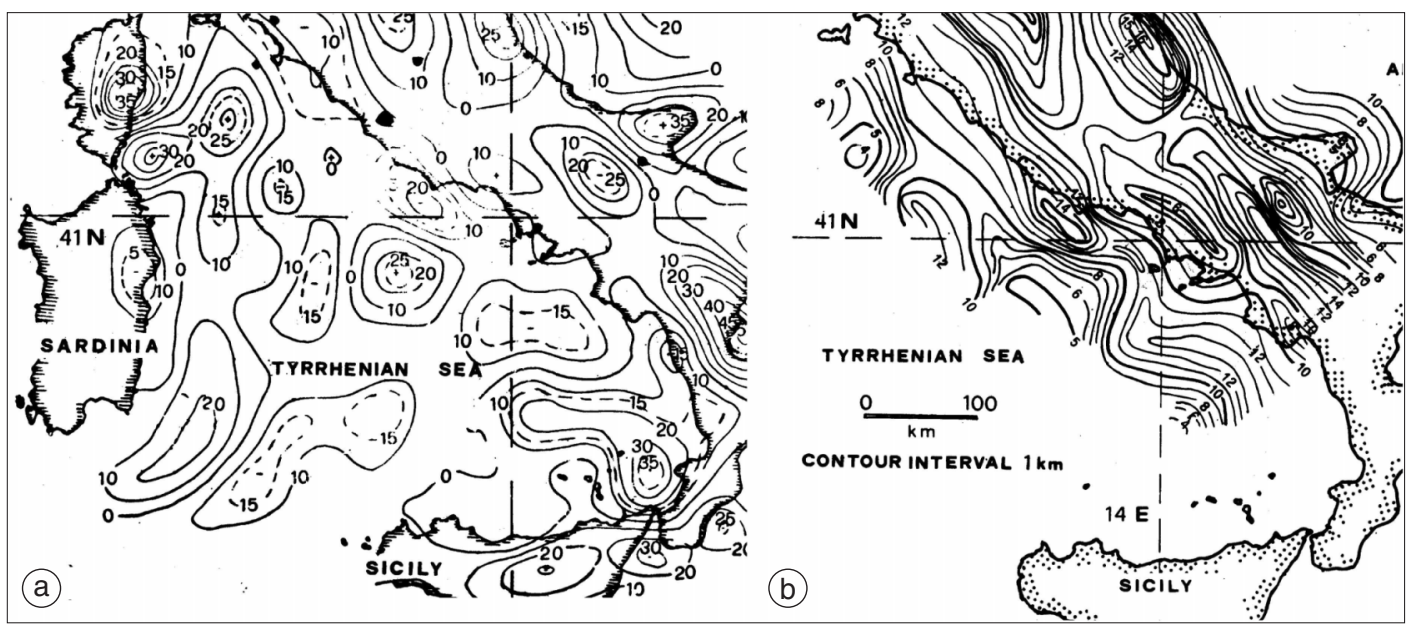

Fig. 5a,b. a) Intermediate wavelength component of the gravity anomaly field (band-pass filter: $100>\lambda>215$ $\mathrm{km})$. Modified from Corrado and Rapolla (1981); b) Depth of the top of the crystalline layer. Modified from Corrado and Rapolla (1981).

anomalies along the continental slopes were explained as due to the presence of peri-tyrrhenian, sediment-filled, troughs.

The Bouguer and terrain data corrections provided a gravity field much smaller than free air, with anomalies strongly decreased in amplitude on several submerged reliefs. The only exception is some volcanoes, like the Marsili and 


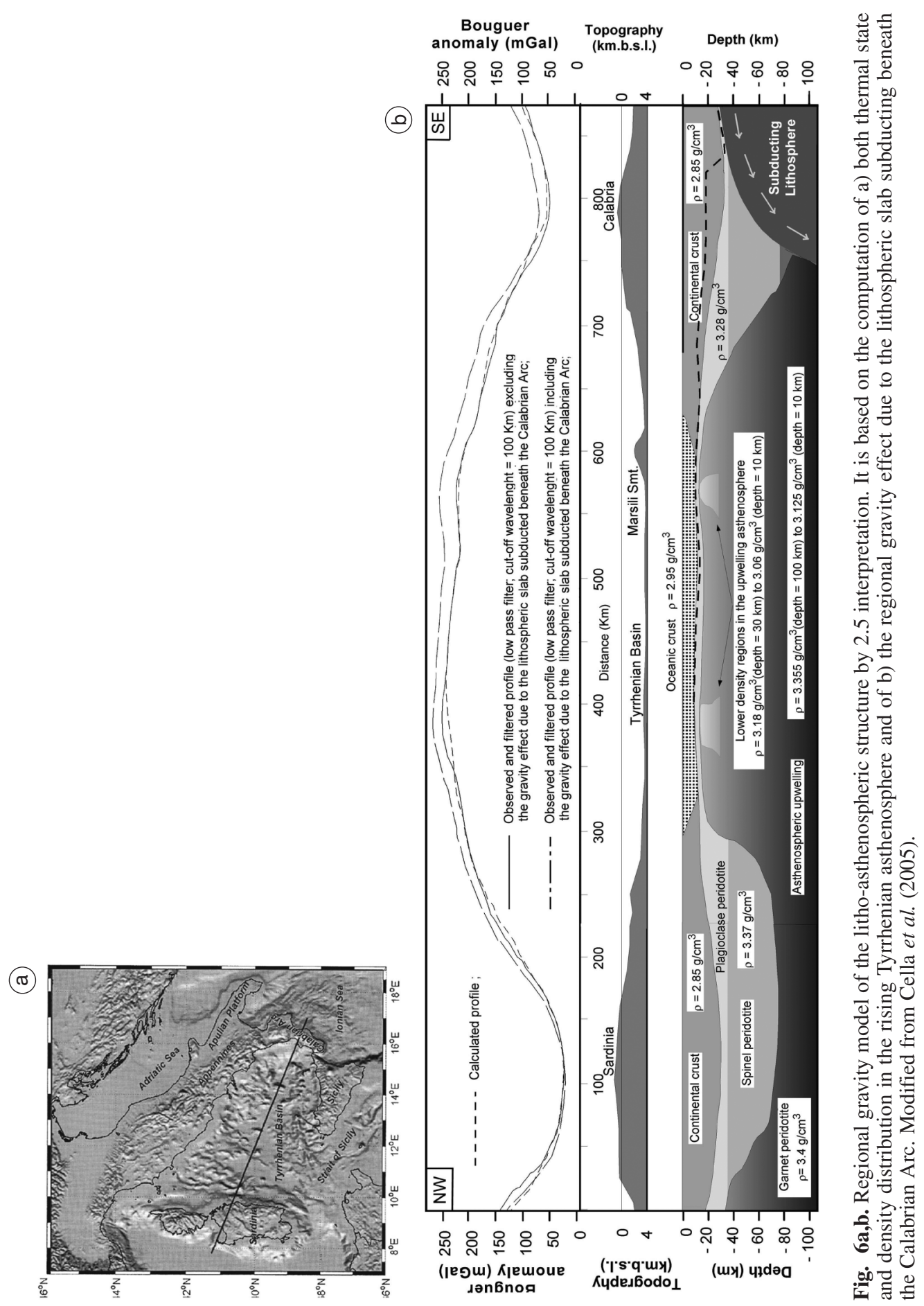


the Vavilov Seamounts, that seemed to have an average density lower than the reference value $\left(2.67 \mathrm{~g} / \mathrm{cm}^{3}\right)$ (Morelli, 1970).

The hypothesis of a strong uprise of the deep discontinuities (Moho and the LAB), beneath the central Tyrrhenian Basin was reinforced by later studies. Pinna and Rapolla (1979) and Corrado and Rapolla (1981) were among the first to provide quantitative information concerning the crustal geometry in the area. They identified the long (fig. 4a) and intermediate (fig. 5a) period components of the Tyrrhenian gravity field and ascribed them to a strong decrease in crustal thickness (up to $15 \mathrm{~km}$ ) beneath the Tyrrhenian bathyal plain (fig. 4b) and to an intra-crustal discontinuity with depths increasing toward the central basin respectively (fig. 5b).

Afterwards, these data were essentially confirmed by further information from both seismic investigations (Steinmetz et al., 1983; Recq et al., 1984; Duschenes et al., 1986; Nicolich, 1989; Suhadolc and Panza, 1989; Scarascia et al., 1994), heat flow studies (Della Vedova et al., 1984; Hutchison et al., 1985; Wang et al., 1989; Cataldi et al., 1995), and deep well sampling (Kastens et al., 1988). Marson et al. (1995) interpreted the regional gravity field along several transects through the Tyrrhenian basin. They assumed a high density body within the upper mantle beneath the Tuscan area and the Southeastern Tyrrhenian and interpreted it as denser Adriatic/Ionian lithospheric slab sinking in the less dense Tyrrhenian asthenosphere.

Cella et al. (1998) interpreted the Tyrrhenian gravity field taking into account not only all the available geophysical information but also a quantitative estimate of the density gradient within the uprising asthenosphere (Cella and Rapolla, 1997) based on a petro-physical modelling suggested by McKenzie and Bikle (1988). The density gradient beneath the Tyrrhenian Basin was computed by means of a «step by step» process consisting in: a) computation of the mantle geotherms starting from basic assumptions ( $T p$ - potential temperature, $\beta$ stretching factor and lithospheric thickness prior stretching); b) computation of the melt fraction degree and its composition; c) computation of the modal norm of the residual mantle rocks after melt segregation. The regional field was cut off by low-pass filtering and interpreted by $2.5 \mathrm{D}$ techniques. The results supported the hypothesis of a passive mantle rising beneath the Tyrrhenian Basin, and a stretching degree indicating a transition from «continental» to «oceanic» rifting (Zito et al., 2003). The previous study was subsequently updated (Cella $e t$ al., 2006) by introducing further improvements in the gravity models by means of a) a better computation of the density distribution within the tyrrhenian rising asthenosphere and b) a modelling of the regional gravity effect due to the lithospheric slab subducting beneath the Calabrian Arc. The slab density model was computed taking into account a) the heating by conduction from the hotter asthenosphere, b) the advection of heat in the moving slab and c) the heating by compression of the asthenosphere. The model (fig. 6) expects: a) asthenospheric top at a depth of 10-15 km beneath the Tyrrhenian bathyal plain instead of $25 \sim 20 \mathrm{~km}$ (Cella et al., 1998), deepening up to $85 \mathrm{~km}$ and $80 \mathrm{~km}$, respectively, beneath the Sardinia micro-plate and the Calabrian Arc (fig. 6); b) continental stretching by lithospheric boudinage within the earlier Alpine-Betic orogen up to a $\beta>6$; c) eastward jumping spreading centers associated with a passive mantle upwelling ( $T p=$ $=1330^{\circ} \mathrm{C}$ ) triggered by d) a westward subducting slab $80 \mathrm{~km}$ thick and $70^{\circ}$ dipping beneath the Calabrian Arc with rates smaller (2-3 $\mathrm{cm} / \mathrm{yr}$ ) than suggested by other studies.

More recently, new gravity studies were carried out in the Tyrrhenian area by means of boundary analysis procedures based on advanced techniques of signal enhancement. Fedi (2002) interpreted the Tyrrhenian gravity field by using the MDA (Multiscale Boundary Analysis). This treats the potential fields as the result of interference among anomalies generated by different sources and provides the numerical computation of high-order vertical derivatives (EHD - Enhanced Horizontal Derivative, Fedi and Florio, 2001). It tends to enhance the signal over the source boundaries and to suppress the other spurious maxima due to the single derivatives of different order, thus providing maps having selective enhancements at different scales. In the Tyrrhenian case, the large scale map (regional patterns) shows a broad 

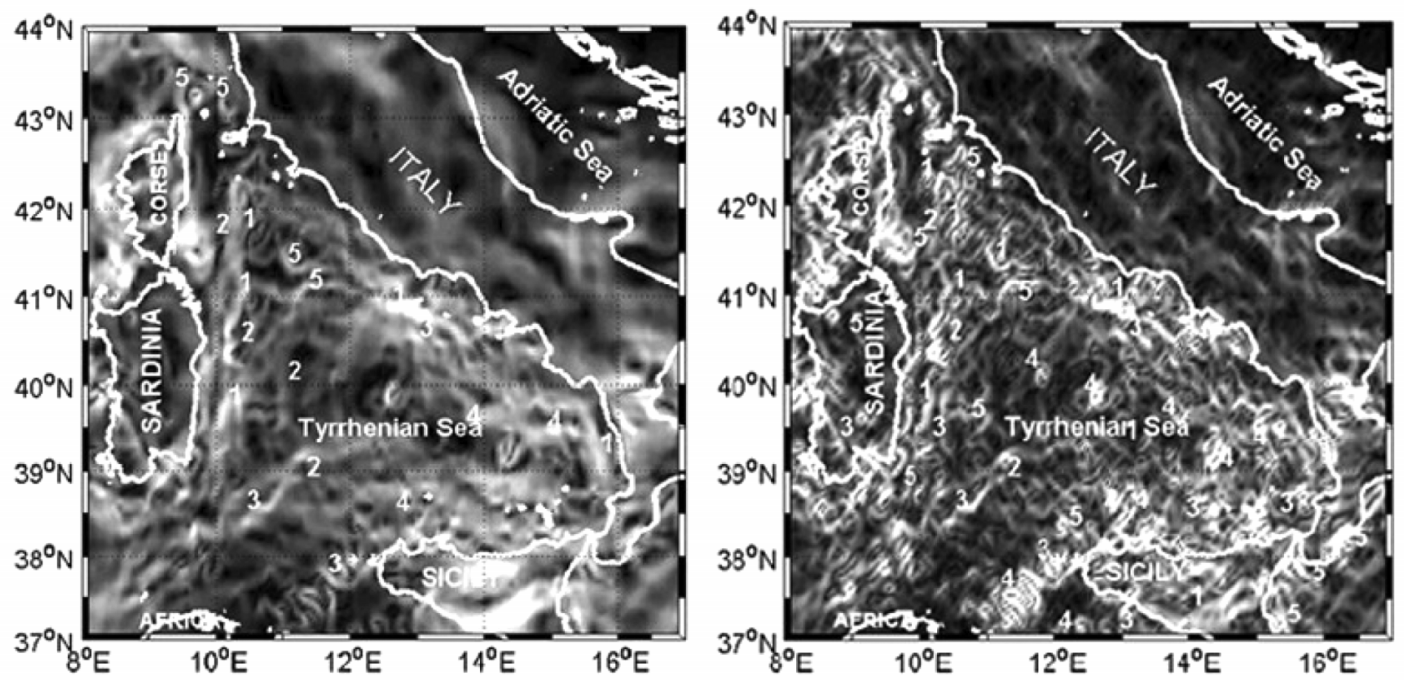

Fig. 7a,b. MDA at short (b) and intermediate (a) of the Tyrrhenian Bouguer gravity field. The map shows main basins (1), plateau and ridges (2), fault systems (3), closed trends (seamounts and islands) (4) and, finally, lineaments not related with known structures (5). Modified from Fedi (2002).

trend of triangular shape surrounding the whole basin. It is presumably due to the lateral increase in crustal and lithospheric thickness from the central area toward the surrounding regions. The short and intermediate scale maps (fig. 7) depict the lateral extent of the buried structures of known morphological elements like: a) basins (Sardinia, Paola, Issel, Magnaghi, Marsili and Giannutri Basins), b) submerged reliefs (Cornaglia Plateau, Elba ridge, Baronie Mountains and other outcropping blocks of acoustic basement) c) fault systems, d) volcanic seamounts and islands (Vavilov, Marsili, Magnaghi, Enotrio, Eolo, Poseidon, Ustica and Anchise). However, the most interesting result concerns lineaments not related to any known structures. This is the case of the trends visible offshore Northern Sardinia, NE and E of Capraia Island, SW of Gorgona Island, and $\mathrm{N}$ of Elba Island. Similarly, another two parallel trends, including the Cornaglia Seamount, are oriented normally (E-W) to the known system faults. Other linear trends seem related to normal faults bordering the Messina Canyon (offshore NorthEastern Sicily). Finally, other trends suggest the existence of NE-SW fault systems, currently only partially known, bordering the South-Eastern rim of the Sardinia microplate.

\subsubsection{Data interpretation at local scale}

With regard to investigations focused on smaller Tyrrhenian districts, the Gulf of Naples has been frequently studied since the Seventies. A first study of gravity and magnetic data was carried out by Carrara et al. (1974) to investigate the shallow crust near Naples, thus evidencing the existence of buried intrusive rocks of higher susceptibility beneath the Campanian Plain. Subsequently, Fedi and Rapolla (1987) carried out a spectral analysis of the gravity field in the Tyrrhenian Sea offshore the Campanian coastline to cut-off gravity effects due to respectively, a) sub-surface sources (i.e.: calderic structures in the Phlegrean Fields), b) shallow intracrustal structures (i.e. the collapsed crystalline basement north of the Pozzuoli Gulf) and c) subcrustal sources (i.e. the abrupt decrease in crustal thickness towards the Tyrrhenian Basin) (fig. 8a-d). This information allowed a crustal modeling be- 

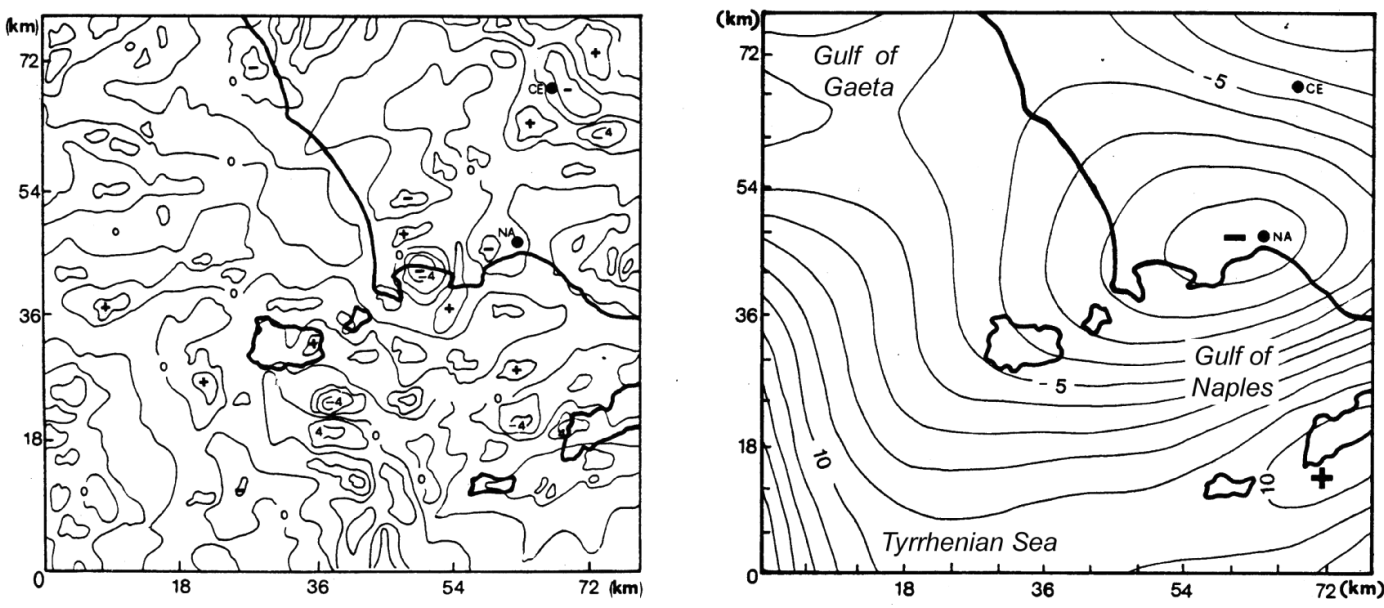

(a)

(C)
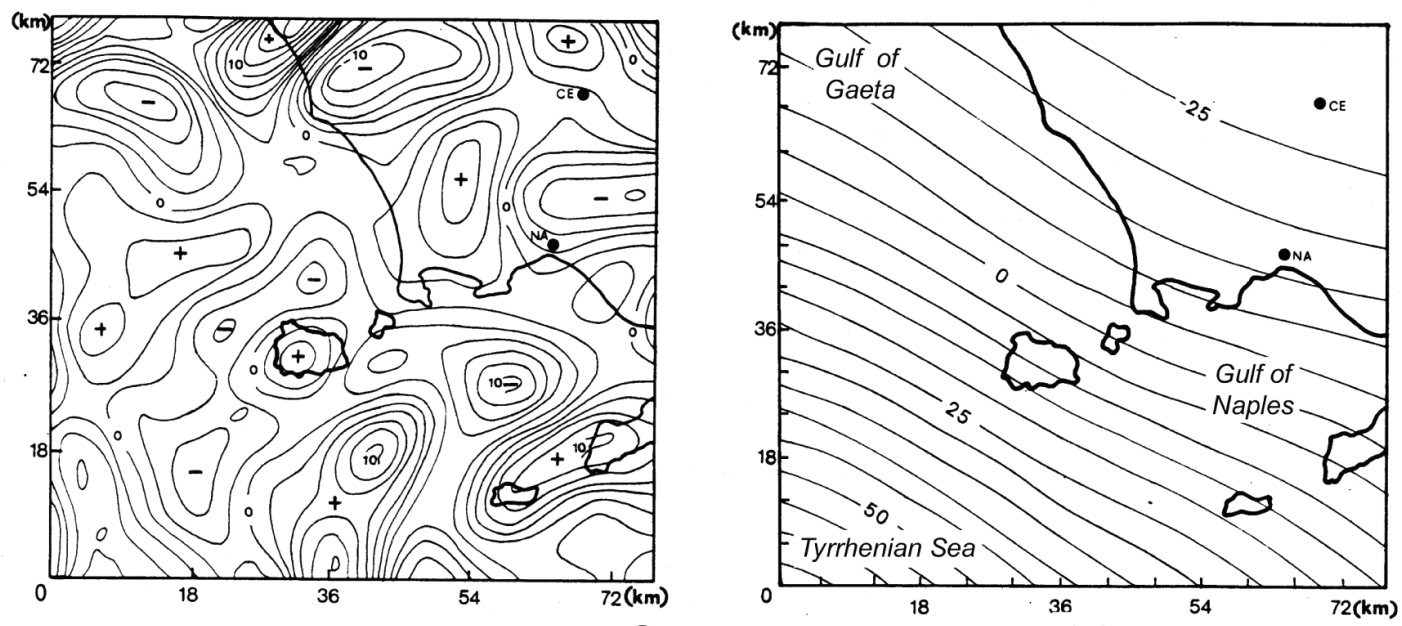

(b)

(d)

Fig. 8a-d. Filtered gravity anomaly maps of the Tyrrhenian Basin offshore Campania: a) $\lambda<12$ km, equidistance $=2 \mathrm{mGal}$; b) $12 \mathrm{~km}<\lambda<40 \mathrm{~km}$, equidistance $=2 \mathrm{mGal}$; c) $40 \mathrm{~km}<\lambda<100 \mathrm{~km}$, equidistance $=3 \mathrm{mGal}$; d) $\lambda>100$ $\mathrm{km}$, equidistance $=5 \mathrm{mGal}$.

neath the Gulf of Naples (Rapolla et al., 1989) that disclosed shallow complex volcanic structures and compositional discontinuities at intermediate and high depths, thus revealing in advance evidence confirmed by more recent studies (Orsi et al., 1996; D’Antonio et al., 1999; Florio et al., 1999; Bruno, 2004; De Astis et al., 2004; Judenherc and Zollo, 2004).
A 3D inversion of the free air anomalies was restricted to the Magnaghi Seamount area (Fedi et $a l ., 1994)$ and revealed that the volcanic relief is an uniformly dense structure except for its western side, probably due to the presence of thick sediments causing a lateral variation in density.

The analysis, by low-pass filtering, of gravity data of the Aeolian Islands, supplied by the 

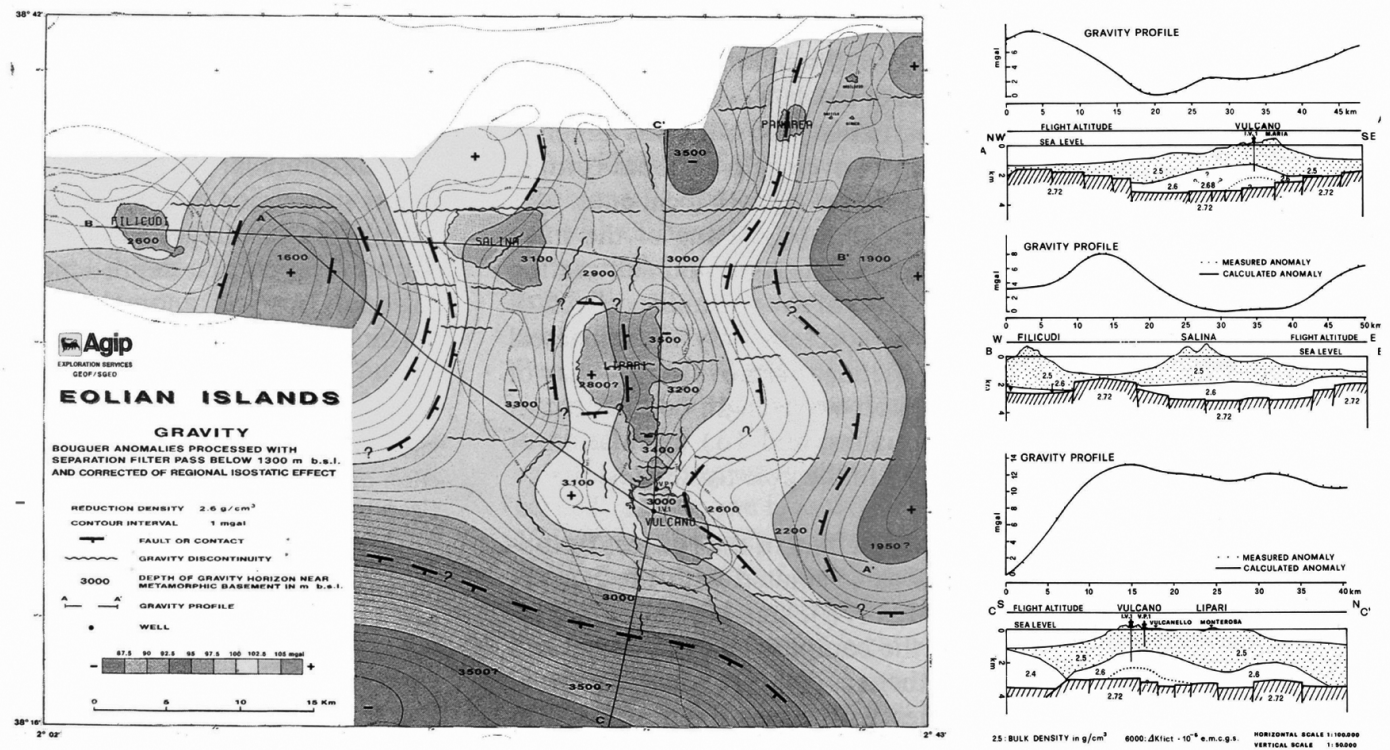

Fig. 9a,b. a) Bouguer anomaly map of the Eolian Islands corrected for isostatic effect; b) Density models from gravimetric data. Modified from Barberi et al. (1994).
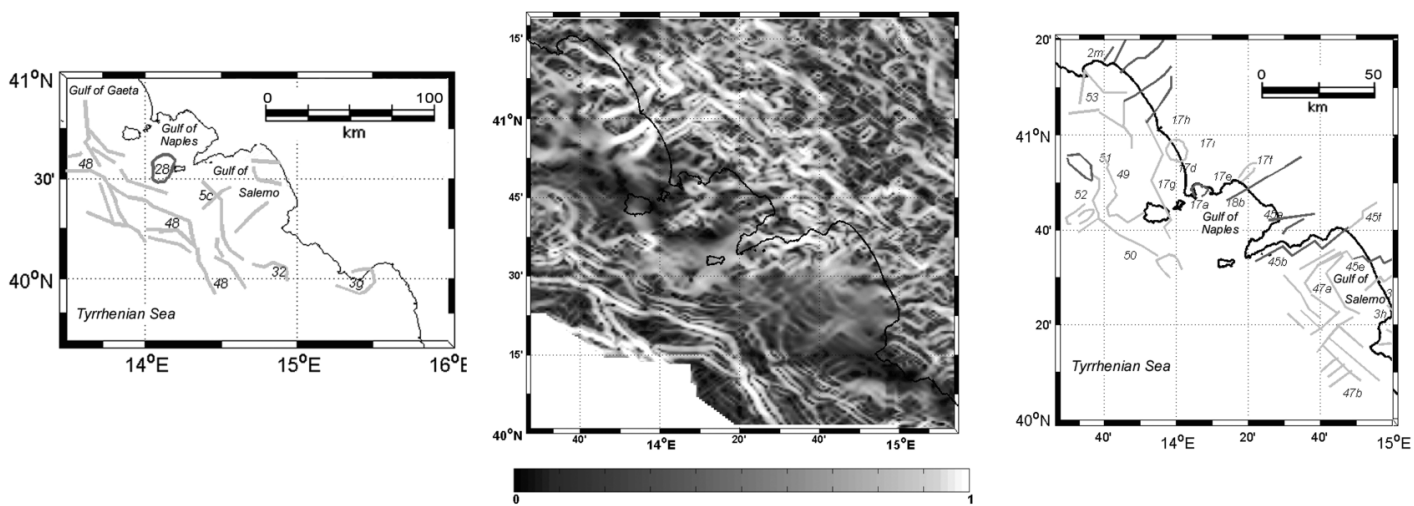

Fig. 10. Major lineaments identified by EHD maxima of the intermediate scale MDA map of Bouguer anomaly gravity field of the Eastern Tyrrhenian Sea offshore the Campanian coast. Dark gray: correlated lineaments; Light gray: uncorrelated or partially correlated lineaments. Lineaments are defined by trends of local maxima which are graphically determined by the colorbar in normalized units. Numerical references: see the text. Modified from Fedi et al. (2003).

AGIP-ENEL-EMS Joint venture, (Barberi et al., 1994) revealed a gravity pattern (fig. 9a) suggesting the existence of a fault-bounded graben-like $\mathrm{N}-\mathrm{S}$ oriented, normally with respect to the vol- canic arc. The 2.5D interpretation (fig. 9b) depicts a three-layered structure including a lower and denser layer, identified as the basement, a less dense upper layer, represented by volcanic 
(a)

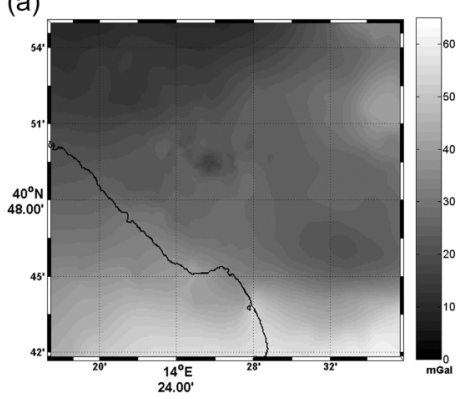

(b)

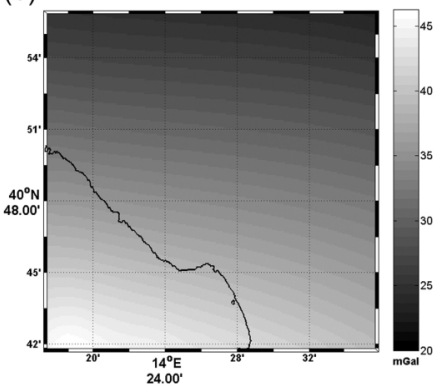

(c)

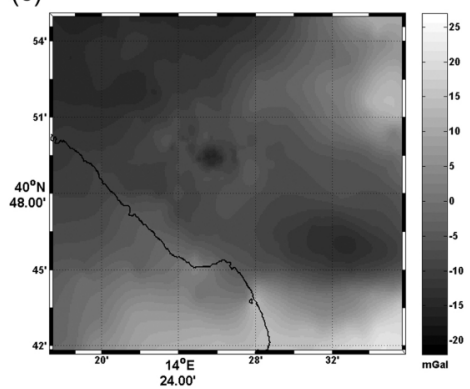

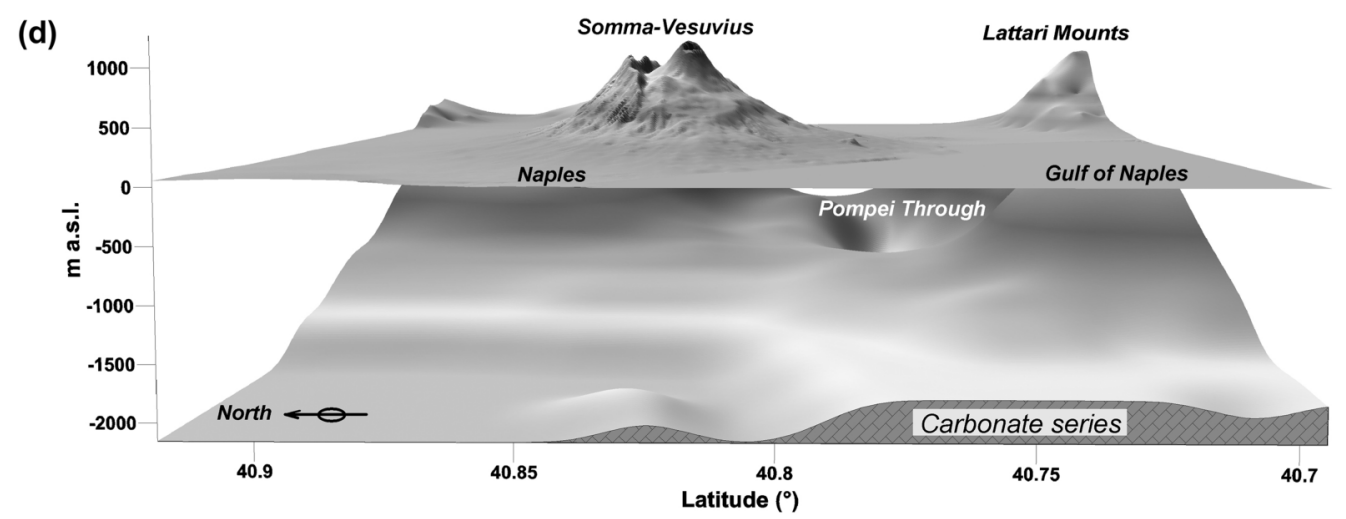

Fig. 11a-d. Model of the top of the carbonate basement buried by the younger marine/volcanic sediments beneath the Gulf of Naples and the Somma-Vesuvius volcanic complex (d). Computed by 3D inversion of the residual gravity field (c). The original and regional fields are showed, respectively, in (a) and (b).

bodies, and an intermediate one, of uncertain nature and interpreted as not necessarily intrusive.

Recently, Fedi et al. (2005) analyzed the MDA (Multiscale Derivative Analysis) signals along the eastern side of the Tyrrhenian Basin, to establish a correlation with the structural setting of the area. They found that a large number of MDA trends cannot be ascribed to any known geological feature. Among them, a closed trend is visible South of the Cilento promontory ( $3 \mathrm{~g}$; fig. 10) without apparent correlation with the outcropping carbonate series of the Bulgheria-Verbicaro Units. Both the intermediate and short scale analysis revealed linear regional trends (48), WNW and NWN oriented (fig. 10), roughly coinciding with normal faults located along the rim of the Tyrrhenian basin and strictly related to its formation. These trends are only partially related to the known structural setting (i.e. in correspondence of the Sirene Mt. $\left(13^{\circ} 50^{\prime} \mathrm{E}-40^{\circ} 20^{\prime} \mathrm{N}\right)$. The linear trends NW-SE and NE-SW directed (47a; fig. 10) could be related to a normal fault system associated to the tectonic depression of the Gulf of Salerno and extend southward, up to the northern Cilento shoreline (47b; fig. 10). Northward, a linear trend (17g; fig. 10) runs from the M. Massico carbonate complex toward Procida and Ischia Islands. Its meaning is not clear and could be related to a fault system displacing the carbonate basement and possibly connecting the Roccamonfina and the Ischia-Phlegraean volcanic districts. Two trends (n. 49 and 50; fig. 10) run NW and NE without any apparent correlation with known structures offshore, toward the Gaeta Gulf. They could be presumably due to the existence of volcanic structures aligned with the 
fault-system bordering the continental shelf south of the Ponziane Islands. In this area two closed trends are visible (n. 51 and 52; fig. 10). Only one of them seems to partially coincide with a small trough between Ventotene Island and the Gulf of Gaeta. Recently the potential field of marginal sections of the Tyrrhenian Basin was interpreted by means of advanced 3D inversion techniques. As an example, the investigation of gravity data in the Bay of Naples and the Somma-Vesuvius volcanic district provided both a density model of the shallow structure beneath the volcano and the bathymetry of the top of the carbonate basement buried by the younger marine/volcanic sediments (fig. 11) (Cella et al., 2007).

\section{The magnetic field of the Tyrrhenian Basin}

\subsection{Geomagnetic surveys}

As for the gravimetric case, the first investigations of the magnetic anomaly field in the Tyrrhenian Sea were carried out from 1965 to 1969 by OGS (Morelli (1970) during several cruises of the r/v Bannock. Between the Seventies and the Eighties the Earth magnetic field was surveyed by the MAGSAT satellite. Measurements provided a map of very long-wavelength magnetic anomalies (Coles et al., 1982; Langel et al., 1982) including the Tyrrhenian Sea and

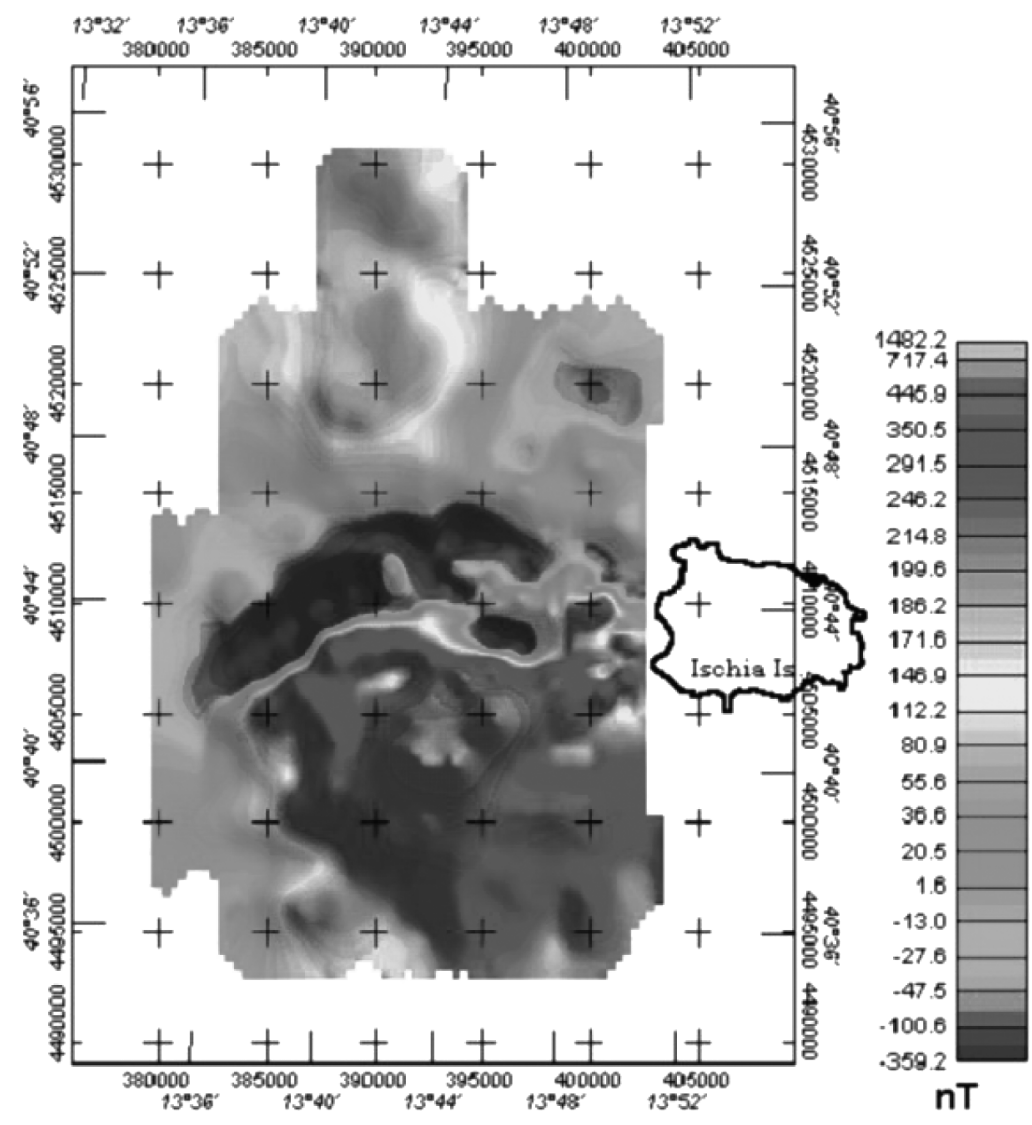

Fig. 12. Ship-borne magnetic survey carried out by GeomareSud during the GMS00_05 Cruise (October 2000). Sampling rate: $4 \mathrm{~s}$. 




Fig. 13a-f. Integrated magnetic map of the Gulf of Naples and of the Campanian Plain obtained by merging different magnetic data sets: a) Helicopter-borne survey in the Vesuvian area (Paoletti et al., 2005a); b) Shipborne survey (R/V Urania) in the Bay of Naples (Marsella et al., 2002; Secomandi et al., 2005); c) Aeromagnetic survey in the Pozzuoli Bay by AGIP (ENI, 1985); d) Helicopter-borne survey in the northern Phlegrean area (Paoletti et al., 2004); e) Magnetic data north of Vesuvius from a regional survey (AGIP, 1981); f) Land survey on Ischia Island (Nunziata and Rapolla, 1987). Modified from Paoletti et al. (2005b).

surrounding districts. An aeromagnetic survey was carried out on the whole basin by AGIP Spa with main and tie lines spaced $5 \mathrm{~km}$ and $10 \mathrm{~km}$ respectively. The residual anomaly map (Cassano, 1984) obtained by subtraction of the IGRF, was published in 1984 in the Carta Aeromagnetica d'Italia (Cassano et al., 1986). This map represented the main data base for most of the later investigations carried out both for local and regional studies. An example is the reduction of this data set to the pole and to the same level (Marson and Panza, 1990).

Recently, a magnetic map was also published by Chiappini et al. (2000), which refers to ground and sea level. Unfortunately, it locally shows a less homogeneous data distribution than the map previously published by AGIP.

A more detailed aeromagnetic map, revisited for the main field correction and with further measurements in addition, is being published by ENI-AGIP (personal communication) preceded by a general description of the potential fields of the Central Mediterranean (Bernardelli et al., 2005).

A few investigations at higher detail were carried out at local scale in the Tyrrhenian area. The first was an aeromagnetic survey completed by CNR in 1970 near Salina, Lipari and Vulcano is- 
lands and surrounding sea. The coverage of the Aeolian Islands was completed in 1985 with a new survey by the AGIP-ENEL-EMS Joint Venture including the area between Filicudi, Panarea and Vulcano.

Several local shipborne geomagnetic surveys, were carried out on restricted areas of geological interest, including the Palinuro Seamount (Smirnov et al., 1980), the Baronie Seamounts (Belaiev et al., 1988), the Vercelli and Vavilov Seamounts (Filin et al., 1988), the Marsili seamount (Kazmin et al., 1990) and other submarine reliefs (Belaiev et al., 1991). More recently, a new magnetic data set (fig. 12) was supplied by a shipborne survey carried out $\mathrm{W}$ of Ischia Island by GeomareSud, during the GMS00_05 Cruise (Bruno et al., 2002).

Vulcano Island and Southwestern Lipari were newly covered by two high-resolution, low-altitude aeromagnetic surveys (Supper et al., 2004; Okuma et al., 2006). A distinct pattern of local highs of magnetisation was revealed, where no magnetic signatures had been previously found.

Recently, a complete magnetic map (fig. 13) of the Neapolitan area was supplied (Paoletti et al., 2005b) by merging different data sets from new local surveys (Nunziata and Rapolla,1987; Marsella et al., 2002; Paoletti et al., 2004; Pao-

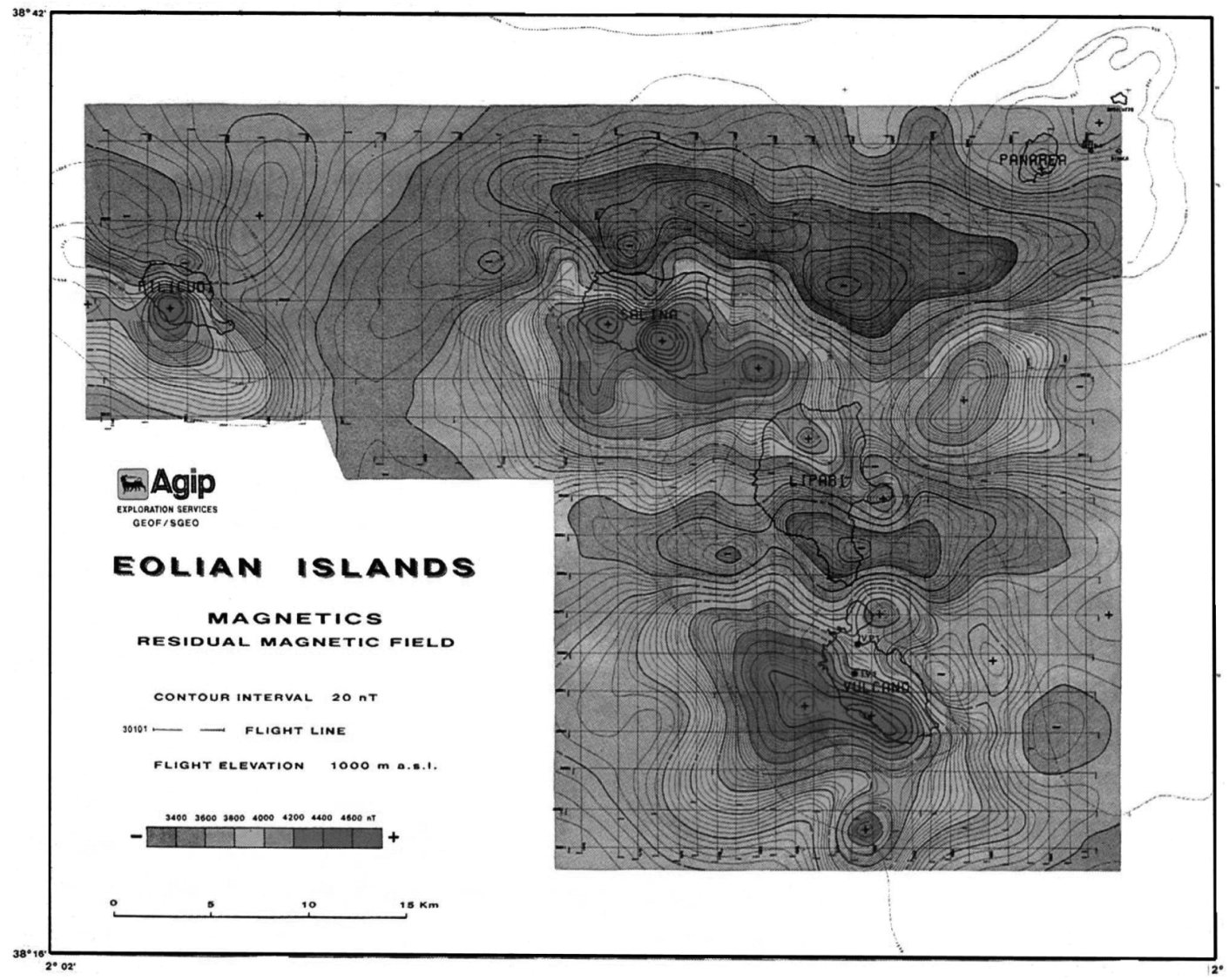

Fig. 14. Magnetic anomaly map of the Eolian Islands after removal of IGRF. Modified from AGIP and Barberi et al. (1994). 
letti et al., 2005a; Secomandi et al., 2005).

A high resolution magnetic survey was recently carried out also over the whole island of Ustica (covered area $=9 \mathrm{~km}^{2}$ ) to investigate the only site in the surroundings showing the subaerial evidence of tectonics related both to the opening of the Thyrrenian basin and the intraplate magmatism (Napoli et al., 2007). Finally, a high resolution aeromagnetic survey performed over the Island of Ischia and its immediate surroundings yielded new information about the structural setting of this area (Paoletti et al., 2009).

\subsection{Description of the geomagnetic anomaly field}

The residual magnetic field of the Tyrrhenian Basin reveals a complex pattern of anomalies variously shaped and extended. A careful comparison with a detailed bathymetric map of the Tyrrhenian, shows a correlation between many of them and volcanic islands, seamounts, tectonic lineaments and morphological highs both within and around the bathyal plain The igneous composition of many of them can be inferred from the high amplitude of the related anomalies.

Several groups of anomalies can be roughly recognized: a first group is associated with the volcanic structures of the Aeolian arc. A second includes the structural elements of the Campania and Lazio volcanic districts. Northward, another group includes sparse anomalies due to igneous structures of the Tuscanian Magmatic Province. Westward, a pattern of anomalies is related to the stretching, faulting and subsidence of the eastern Sardinian continental edge. Finally, a further group of high amplitude anomalies is related to the basic magmatism and its related volcanic centers within the bathyal plain (i.e. Marsili, Magnaghi, Vavilov Seamounts).

The existence of different structures (i.e. transform faults) inferable from the magnetic chart and not easily detectable by means of simple morpho-structural analysis was already pointed out by Selli (1981). It was afterwards detailed by Cassano (1990) that individuated several geomagnetic domains within the Tyrrhenian Basin. Iacobucci et al. (1977) computed the residual field from magnetic data supplied by CNR for the Eolian area. Small anomalies with amplitudes of about $150 \mathrm{nT}$ were highlighted and ascribed both to the shallow volcanic structure and to sequences of lavas and pyroclastic materials.

Still in the Aeolian area, the magnetic map (fig. 14) supplied by AGIP-ENEL-EMS shows several short wavelength magnetic anomalies presumably related to changes in susceptibility within the shallow volcanic series (Barberi et al., 1994). Several anomalies were detected near Volcano Island: a) $4 \mathrm{~km}$ south of Vulcano where magnetic bodies are present along the the Letojanni-Tindari tectonic line; b) east of Vulcano, in a recent eruptive center (1880-1890); c) west of Vulcano where no significant correlation with structural features is visible; d) near Piano Caldera and Vulcanello.

Two small period anomalies are visible at Lipari Island and one of them seems to be associated with the pre-tyrrhenian andesitic volcanism. Other andesitic eruptive centers coincide with anomalies near Salina and in Filicudi Island. Finally, a structural belt extending eastward from Salina is correlated to another long wavelength anomaly.

The local magnetic surveys carried out above the Tyrrhenian bathyal plain provided partial magnetic maps of the greatest Tyrrhenian seamounts (Smirnov et al., 1980; Filin et al., 1988; Kazmin et al., 1990; Belaiev et al., 1991), depicting anomalies with complex shape.

\subsection{Data interpretation and magnetic modelling}

Regional magnetic data supplied by the MAGSAT mission at different elevations for the Mediterranean area were processed by Fedi et al. (1986) and led to the identification of some anomalies of crustal origin by calculating spherical harmonic coefficients of the Earth magnetic field. After suppressing the lowest terms (assumed as the main field), the residual signal was band-pass filtered to separate the sole crustal contribution. Changes in crustal thickness are at a scale too small to be detailed by MAGSAT data. Only the long-wavelength anomaly roughly coinciding with the Corsica- 

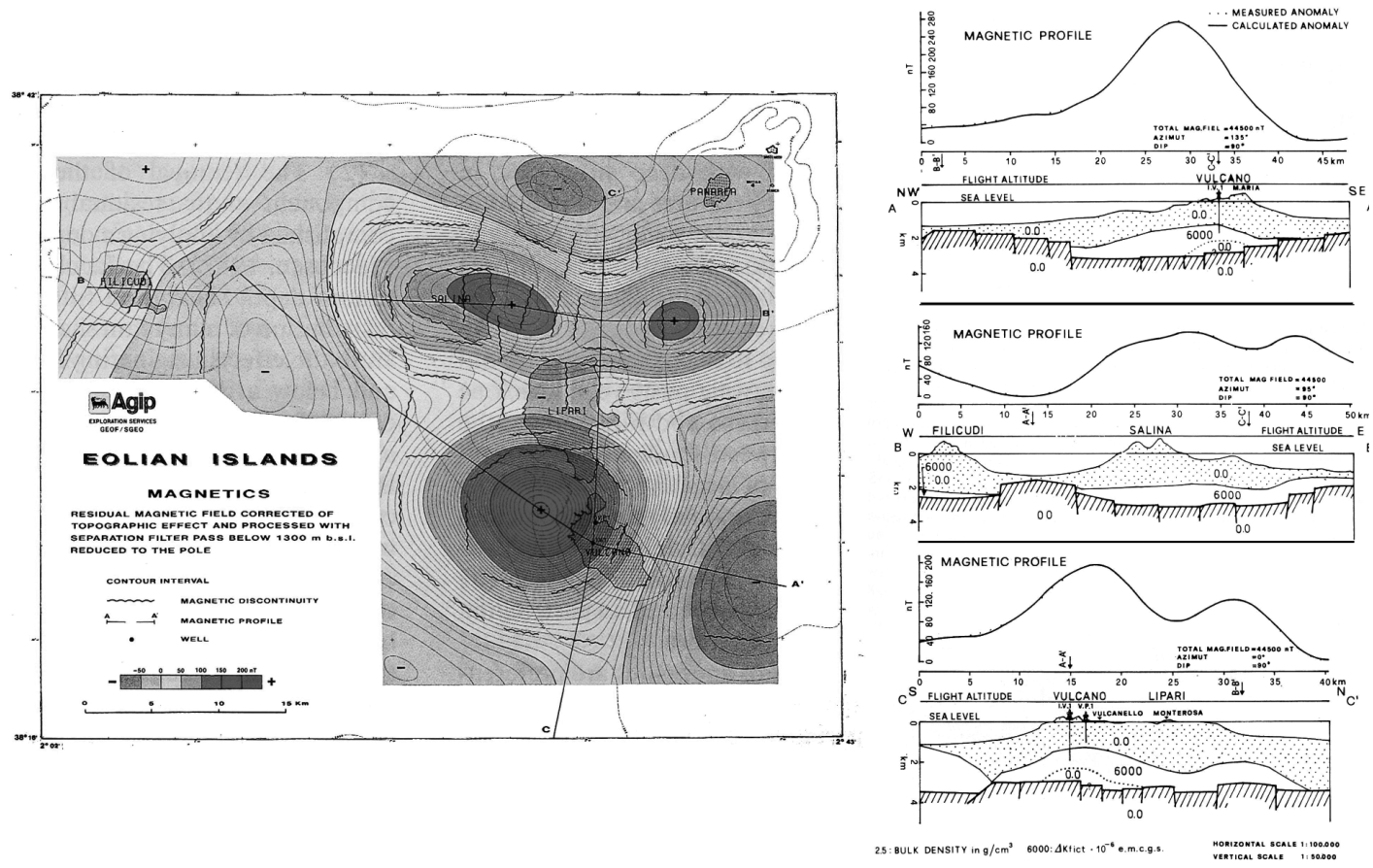

Fig. 15a,b. a) Residual magnetic anomaly map of the Eolian Islands (shown in fig. 31) corrected for the topographic effect, reduced to the pole and low-pass filtered. Modified from AGIP and Barberi et al. (1994); b) Eolian Islands: 2D models from magnetic data. Modified from Barberi et al. (1994).

Sardinia microplate shows a correlation with regional structures, whereas the weak positivity of the surrounding area was explained as due to the Balearic and Tyrrhenian basins. According to Fedi et al. (1986) crustal thinning, high heat flow and crustal composition of these basins, could give a somewhat elevated susceptibility which might be increased by the Hopkinson effect (Dunlop, 1974; Wasilewsky and Mayhew, 1982). Further interpretations at a shorter scale were not possible because the rough detail did not allow investigations at intra-crustal depth.

At a local scale, the magnetic data supplied by CNR for the Eolian Islands were interpreted by Iacobucci et al. (1977) along a NNW-SSE profile by means of $2 \mathrm{D}$ techniques. The resulting two-layered model showed how the depth of the interface between the volcanic cover and the basement changes from $5-6 \mathrm{~km}$ beneath Vulcano and Salina islands to $2 \mathrm{~km}$ beneath Li- pari Island.

Fedi and Rapolla (1987) interpreted the AGIP (1981) data set in the area offshore Lazio and Campania and observed that the setting up normally used to reduce the pole anomalies E of Ischia Island (Roccamonfina, Somma-Vesuvius, etc.) is not optimal for the strong anomaly located $\mathrm{W}$ of Ischia Island and for several other Tyrrhenian anomalies.

These results led the authors to suggest that some highly magnetized crustal masses underwent strong rotational processes after their origin, this having consequences on the geodynamic framework of the Tyrrhenian Sea. Therefore, Fedi and Rapolla (1988) distinguished Tyrrhenian magnetic anomalies into two main groups: the first including anomalies with N-S maximum-minimum alignment and in agreement with the actual declination of the main field; the second having declination values 
ranging from $-30^{\circ}$ to $60^{\circ}$ and correlated to several seamounts. If the induction field direction is assumed to be constant, this implies, at intermediate latitude, a remnant magnetization not aligned with the present inducing field. In the Tyrrhenian case, a strong remanence results in igneous rocks sampled within the corresponding body sources that, therefore, underwent strong rotational movements when their permanent magnetization was recorded during rock cooling. The abnormal maximum-minimum axis direction in these anomalies is not modified even after upward continuation at high elevation, thus confirming that a) they are originated within the intermediate/lower crust, b) the remnant magnetization represents a significant part of the net magnetization at such depths and c) their abnormal shape is not due to a simple body-shape effect (Fedi and Rapolla, 1990; Fedi et al., 1990). Since most of these anomalies are associated with very young volcanic centers (i.e. the Vavilov and Marsili seamounts, aged less than $2 \mathrm{Ma}$ ), a recent counterclockwise rotation of the emerging Apennine chain was inferred, thus providing some of the most significant geophysical evidences along with paleomagnetic studies (Incoronato and Nardi, 1987), of the asymmetrical opening of the Tyrrhenian Basin. This conclusion had noticeable implications with regard to the reconstruction of the geodynamic events in the Central Mediterranean. A similar rotation apparently occurred also in Northern Calabria (Cifelli et al., 2007) whereas a clockwise rotation affected the
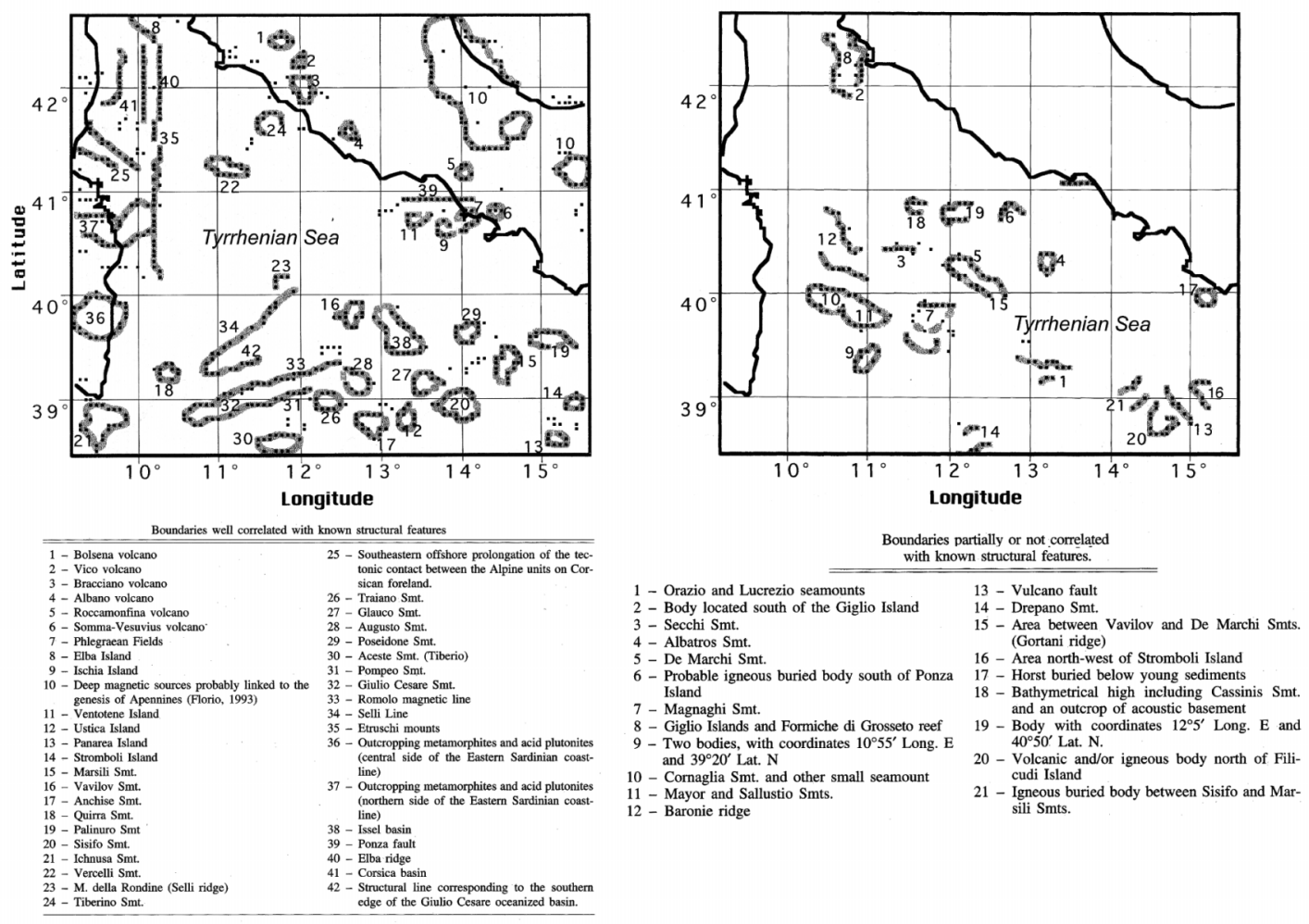

Fig. 16a,b. Main trends of maxima of the analytic signal evidencing structures (a) already recognized in previous studies and (b) not correlated with known features. Dots individuate the location of the maxima values of the analytic signal. For numerical references see table. Modified from Cella et al. (1998). 

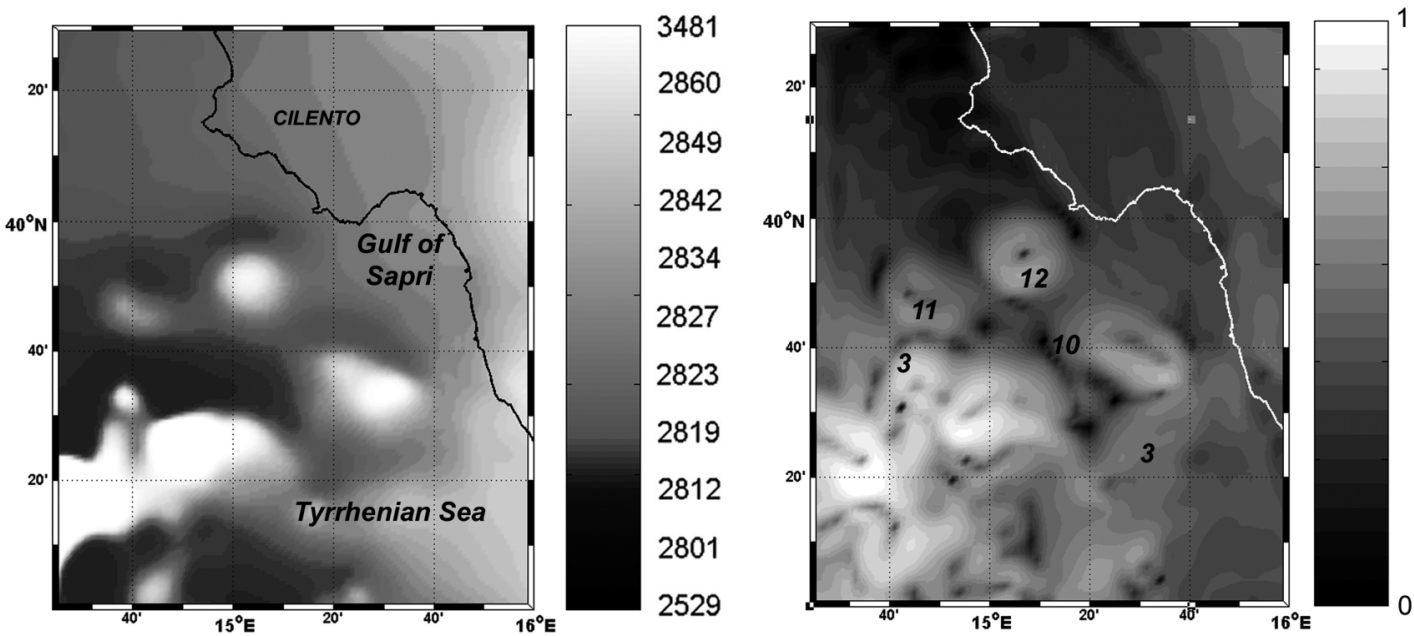

Fig. 17a,b. a) Magnetic anomaly map of the Southeastern Tyrrhenian Sea. Modified from Fedi et al. (2005); b) Intermediate scale MDA map of aeromagnetic data in Southeastern Tyrrhenian Sea. For references to lineament numbers: see text. Lineaments are identified by trends of maxima and graphically determined by the shown color bar in normalized units. Modified from Fedi et al. (2005).

southern side of the Calabrian Arc (Cifelli et al., 2007). This agrees with Besse et al. (1984), who assumed a clockwise torsion of the Calabrian arc since the Middle-Upper Miocene as a consequence of the decoupling between the African and Adriatic plates (Mantovani et al., 1985). No significant rotations seem to have occurred in the area at least since the middle Pleistocene (Cifelli et al., 2004).

At local scale, aeromagnetic data supplied by AGIP-ENEL-EMS for the Aeolian area were interpreted (Barberi et al., 1994) by means of $2.5 \mathrm{D}$ techniques (fig. 15a), providing a threelayered model (fig. 15b) with a typical horst/graben structure where the top of the basement, ranges from $1500 \mathrm{~m}$ to $3500 \mathrm{~m}$ of depth (Barberi et al., 1994).

The magnetic field of the bathyal plain including the Magnaghi Seamount was investigated by a 3D magnetic inversion (Fedi et al., 1994) that revealed lateral changes in magnetization as relevant as the vertical ones. In fact, the western margin of the relief appears the most magnetized part of the submerged relief.

Based on the interpretation of magnetic data sets covering the main Tyrrhenian seamounts, several authors (Smirnov et al., 1980; Filin et al., 1988; Belaiev et al., 1988; Kazmin et al.,1990; Belaiev et al. 1991) provided an estimation of the effusion rates of the volcanic centers and reinforced the hypothesis of an eastward migration of oceanic magmatism between 8 and 2 Ma BP (Faggioni et al., 1995).

Still concerning studies at local scale, the magnetic field of the south-eastern edge of the Bay of Naples and the Somma-Vesuvius volcanic district has been interpreted by means of a 3D inversion technique. High magnetisations decreasing from the surface to a depth of $2 \mathrm{~km}$ were evidenced, whereas the lack of magnetization below $2 \mathrm{~km}$ was ascribed to the presence of the carbonate basement. (Fedi et al., 1998).

As in the gravity case, the magnetic field of the Tyrrhenian Basin has also been investigated by means of new techniques of signal enhancing aimed at the boundary analysis of the main causative magnetized bodies. Cella et al. (1998) calculated the analytic signal (Nabighian, 1984) of the Tyrrhenian aeromagnetic data set supplied by AGIP (Cassano, 1984). In fact, the maxima of 
the analytic signal mark the boundaries of the causative body independently from parameters (directions of inducing field and magnetization vectors) that can strongly change, as in the Tyrrhenian case. The resulting map revealed a large number of circular patterns correlated to intrusive bodies, submarine volcanoes and outcropping fragments of crystalline basement (fig. 16a). Some of them are located along linear trends of maxima and could be related to extensional tectonics and basement dislocation indicative of possible preferential pathways of magma rise. Many trends do not seem to have any clear reference with known seabed structures (fig. $16 \mathrm{~b}$ ), because these are buried by younger sediments and do not outcrop at the sea floor or have different shape and/or extent unlike that previously predicted.

The MDA technique, was again used by Fedi et al. (2005) to better outline structural features by analyzing the magnetic field of the south-eastern Tyrrhenian Sea (fig. 17a). Here, a strong EHD signal is correlated with several isolated magmatic/volcanic bodies. As an example, north of the Aeolian Islands, three circular trends were identified and indicate the presence of isolated magnetic bodies. The first of them, previously interpreted as outcrops of the acoustic basement (Bigi et al., 1983), could be associated with the Enotrio and Diamante seamounts (n.10; fig. 17b). The high EHD values suggest high magnetization and reinforce the hypothesis of an igneous basic composition within a low susceptible shallow crust. The same could be inferred for two other magnetic sources marked by circular trends offshore the Cilento shoreline (11 and 12; fig. 17b), where no igneous bodies have been reported yet.

At a local scale, the boundary analysis of the data supplied by the GMS00_05 Cruise showed linear as well as subcircular patterns (Bruno et al., 2002). The linear patterns are not correlated with the bathymetry but are oriented with antiapenninic trend consistent with the regional alignment of magnetic and volcanic structures (Ischia-Procida-Phlegrean Fields). The subcircular patterns are clearly correlated with the bathymetry and therefore may be interpreted as (monogenic) volcanic vents (Bruno et al., 2002).
Still near the Neapolitan volcanic district, the correlation between magnetic data (Paoletti et al., 2005b) and known structural elements, revealed several magnetic structures, interpreted as lava and/or pyroclastic domes and local vents. These are aligned along known faults that predate the local volcanism and are preferential routes of magma upwelling. This confirms that the Neapolitan volcanism in the Bay of Naples is controlled by both a pre-Pleistocenic NE-SW and, more recently, NW-SE regional-stress regime. Several circular trends clearly show lateral boundaries of buried volcanic structures offshore the Somma-Vesuvius volcano, thus suggesting the presence of volcanic fields not only in the Phlegrean area, but also near the Somma-Vesuvio district. By contrast, the absence of correspondence between magnetic boundaries and faults in the southeastern sector of the Bay of Naples indicates a sedimentary area without volcanic activity.

\section{Conclusions}

The advances in the collection, analysis and interpretation of gravity and magnetic data in the Tyrrhenian Basin provided a significant contribution to the investigation of the large scale structures and geodynamic evolution of this area in the light of the new global theories. As an example, the earliest results concerning reliable values of crustal thickness beneath the Tyrrhenian Basin were provided by regional gravity investigations (Pinna and Rapolla, 1979; Corrado and Rapolla, 1981).

The $2.5 \mathrm{D}$ inversion of the regional gravity field (Cella et al, 1998; Cella et al., 2006), together with a petro-physical modelling of the asthenosphere-lithosphere system in the Tyrrhenian Basin, led to a better definition of a) the passive asthenospheric upwelling beneath the bathyal plain, b) the subduction processes beneath the Calabrian Arc and c) the Moho and LAB depth changes.

A major advance in Tyrrhenian geodynamics was also given by studies of the magnetic anomalies with abnormal shape existing in the area. As an example, a counterclockwise rotation of the Italian Peninsula was recognized thus 
agreeing with the recent anomalous Tyrrhenian opening toward SE (Fedi and Rapolla, 1988; Fedi and Rapolla, 1990; Fedi et al., 1990).

At a shorter scale, the gravity and magnetic fields of the Tyrrhenian Basin were interpreted by means of new techniques of signal enhancement and boundary analysis, disclosing many structural lineaments not correlated to known elements but with an information content useful for geological interpretation.

The available data sets revealed that the gravity and magnetic fields have a small scale complexity much greater than believed. However, except for a few surveys covering small areas, the low detail did not point out the short wavelength features of the anomaly fields.

This represents a serious drawback because the great increase in power computation, as well as the availability of new reliable techniques of data processing and interpretation could manage a very large amount of data. Therefore, a real advance in gravity and magnetic studies is currently prevented only by a lack of data.

Consequently, the planning of new surveys to integrate the available data sets and to increase the detail of the information would represent a decisive step to reveal very small scale structures and to clarify their geological meaning.

\section{Acknowledgements}

This research was financed by a INGV grant to one of us (A.R.).

\section{REFERENCES}

Agenzia Generale Italiana Petroli (Agip) (1981): Carta Aeromagnetica d'Italia, (Atti Ministeriali Direzione Esplorazione Idrocarburi, S. Donato Milanese, scale $1: 500,000,1$ sheet).

Barberi, F., A. Gandino, A. Gioncada, P. La Torre, A. Sbrana and C. ZenucChini (1994): The dedep structure of the Eolian Arc (Filicudi-Panarea-Vulcano sector) in light of gravity, magnetic and volcanological data, J. Volcanol. Geotherm. Res., 61, 189-206.

Belaiev, I.I., Y.V. Brusilovsky, A.M. GoRODNITSKY, K.V. Popov, A.A. SchreIDER and V.P. SCHERBAKOV (1988): Results of geomagnetic study of the Baronie Ridge (Tyrrhenian Sea), Phys. Earth, 10, 76-82 (in Russian).

Belaiev, I.I., Y.V. Brusilovsky, A.M. GoRodNitsky, K.V. Popov, A.M. FILIN and A.A. SchreIDER (1991): Geomagnetic study of the Tyrrhenian Basin seamounts,
Bull. Mosc. Soc. Nat. Geol., 66 (3), 45-61 (in Russian). Bellucci, F., M. Grimaldi, L. Lirer and A. Rapolla (1997): Structure and geological evolution of the island of Ponza, Italy: inferences from geological and gravimetric data, J. Volcanol. Geotherm. Res., 79, 87-96.

Bernardelli, P., C. Cavalli, R. Longoni and I. Giori (2005): Gravity and magnetic fields of the Central Mediterranean region, in CROP Deep Seismic Exploration of the Mediterranean Region, edited by I.R. FINETTI (Elsevier), 57-67.

Berrino, G., G. Corrado and U. Riccardi (1998): Sea gravity data in the Gulf of Naples: a contribution to delineate the structural pattern of the Vesuvian Area, $J$. Volcanol. Geotherm. Res., 82, 139-150.

Besse, J., J.-P. Pozzi, G. Mascle and H. Feinberg (1984): Paleomagnetic study of Sicily: consequences for the deformation of Italian and African margins over the last 100 million years, Earth Planet. Sci. Lett., 67 (3), 377-390.

Bigi, G., D. Cosentino, M. Parotto, R. Sartori and P. ScAndone (1983): Structural Model of Italy (Scale 1:500.000), (published by the CNR from «Progetto Finalizzato Geodinamica» - Sottoprogetto «Modello Strutturale Tridimensionale»).

Bozzo, E., G. Corrado, A. Elena, O. Faggioni and E. PinNA, (1984): Magnetic anomalies and deep crustal structure along the Elba-Levanto-Ottone Varzi Line, Boll. Geofis. Teor. Appl., 26, 67-75.

BRUNO, P.P. (2004): Structure and evolution of the Bay of Pozzuoli (Italy) by marine seismic data, Bull. Volcanol., 66, 342-355, doi:10.1016/s0040-1951(03)0,327-5.

Bruno, P.P., G. De AlteriIs and G. Florio (2002): The western undersea section of the Ischia volcanic complex (Italy, Tyrrhenian Sea) inferred by marine geophysical data, Geophys. Res. Lett., 29 (9), 57-1/57-4.

BUREAU GRAVIMETRIQUE INTERNATIONAL (1971): Anomalies de Bouguer, Europe-Afrique, (3rd edition, Paris).

Carrara, E., F. Iacobucci, E. Pinna and A. Rapolla (1974): Interpretation of gravity and magnetic anomalies near Naples, Italy, using computer techniques, Bull. Vulcanol., 38 (2), 1-10.

CAssano, E. (1984): Rilievi magnetici per la ricerca mineraria, in Atti del $1^{\circ}$ Convegno di Geomagnetismo, 23-24 Ottobre 1984, Roma, Italy, 117-163.

Cassano, E. (1990): Tyrrhenian and Western Mediterranean geomagnetic domains, Terra Nova, 2, 638-644.

CAssano, E., R. Fichera and F. Arisi Rota (1986): Rilievo aeromagnetico d'Italia. Alcuni risultati interpretativi, in Atti V Conv. Naz. G.N.G.T.S, 939-958.

Cassano, E., L. Anelli, V. Cappelli, I. Giori and P. La TORRE (2001): The island of Elba - Northern Tyrrhenian Sea - Aeromagnetic and gravity data, Ofioliti, 26 (2a), 153.

Cataldi, R., F. Mongelli, P. Squarci, L. Taffi, G. Zito and C. CALORE (1995): Geothermal ranking of Italian territory, Geothermics, 1, 115-129.

Cella, F. and A. Rapolla (1997): Density changes in upwelling mantle, Phys. of the Earth and Planet. Int., 103 (1-2), 63-84.

Cella, F., F. Fedi, G. Florio and A. Rapolla (1998a): Optimal gravity modelling of the litho-asthenosphere system in Central Mediterranean, Tectnophysics, 287 (14), 117-138. 
Cella, F., F. Fedi, G. Florio and A. Rapolla (1998b): Boundaries of magnetic anomaly sources in the Tyrrhenian Region, Ann. Geofis., 41 (3), 433-447.

Cella, F., S. de LoRenzo, M. Fedi, M. Loddo, F. MongelLI, A. RAPOLLA and G. ZiTO (2006): Temperature and density of the Tyrrhenian lithosphere and slab and new interpretation of gravity field in the Tyrrhenian Basin, Tectonophysics, 412 (1-2), 27-47.

Cella, F., F. Fedi, G. Florio, M. Grimaldi and A. RapolLA (2007): Shallow structure of the Somma-Vesuvius volcano from 3D inversion of gravity data, J. Volcanol. Geotherm. Res., 161, 303-317.

Cifelli, F., M. Mattei, F. Rossetti (2007): Tectonic evolution of arcuate mountain belts on top of a retreating subdiction slab: The example of the Calabrian, Arc. Journal of Geophisical Research, 112.

Cifelli, F., F. Rossetti, M. Matteria, A.M. Hirt, R. FuniCIELLO and L. TORTORICI (2004): An AMS, structural and paleomagnetic study of quaternary deformation in eastern Sicily, J. Struct. Geol., 26, 29-46.

Chiappini, M., A. Meloni, E. Boschi, O. Faggioni, N. Beverini, C. CARMisciano and I. Marson (2000): Onshore-offshore shaded relief integrated magnetic anomaly map at sea level of Italy and surrounding areas, scale 1:500000, Ann. Geofis., 43 (5), Plate 1.

Coles, R.L., G.V. Haines, G. Jansen Van Beek, A. Nandi and J.K. WALKER (1982): Magnetic anomaly from $40^{\circ} \mathrm{N}$ to $83^{\circ} \mathrm{N}$ derived from MAGSAT data, Geophys. Res. Lett., 9, 281-284.

Corrado, G. and A. RAPOLla (1981): The gravity field of Italy: analysis of its spectral composition and delineation of a tridimensional crustal model for centralsouthern Italy, Boll. Geofis. Teor. Appl., 23, 17-29.

D’antonio, M., L. Civetta, G. Orsi, L. Pappalardo, M. Piochi, A. Carandente, S. DeVita, M. Di Vito and R. ISAIA (1999): The present state of the magmatic system of the Campi Flegrei caldera based on a reconstruction of its behaviour in the past $12 \mathrm{ka}, \mathrm{J}$. Volcanol. Geotherm. Res., 91, 247-268.

De Astis, G., L. PAPPAlardo and M. Piochi (2004): Procida volcanic history: New insights into the evolution of the Phlegraean Volcanic District (Campania Region, Italy), Bull. Volcanol., 66 (7), 622-641.

Della Vedova, B., G. Pellis, J.P. Foucher and J.-P. ReHAULT (1984): Geothermal structure of the Tyrrhenian Sea, Mar. Geol., 55, 271-289.

Dunlop, D.J. (1974): Thermal enhancement of magnetic susceptibility, J. Geophys., 40, 4339-4551.

Duschenes, J., K.E. Louden and M.C. SinHa (1986): A seismic refraction experiment in the Tyrrenhian Sea, Geophys. J. R. Astron. Soc., 85, 139-160.

Ente NAZionale Idrocarburi (ENI) (1985): Rapporto «hunting geology and geophysics» internal report, ENI SpA, (Exploration and Production Division, S. Donato Milanese), 38.

Faggioni, O., E. Pinna, C. Savelli and A.A. Schreider (1995): Geomagnetism and age study of Tyrrhenian seamounts, Geophys. J. Int., 123, 915-930.

FEDI, M. (2002): Multiscale derivative analysis: a new tool to enhance detection of gravity source boundaries at various scales, Geophys. Res. Lett., 2, 16-1-16-4.

FedI, M. and G. Florio (2001): Potential fields source boundaries detection by an Enhanced Horizontal De- rivative, Geophys. Prospect., 49 (1), 13-25.

Fedi, M. and A. RAPOLLA (1987): The Campanian Volcanic Area: analysis of the magnetic and gravimetric anomalies, Boll. Soc. Geol. It., 106, 793-805.

FedI, M. and A. Rapolla (1988): Rotation of the Italian peninsula from aeromagnetic evidence, Phys. Earth Planet. Inter., 52, 301-307.

FEDI, M. and A. Rapolla (1990): Shape analysis of aeromagnetic anomalies in the Southern Italian Region for the evaluation of crustal block rotations, J. Geodyn., 12 (2-4), 149-161.

Fedi, M., P. Gasparini, M.S.M. Mantovani, F. Monaco and D. PieratTini (1986): Magsat anomalies of crustal origin in Europe, Boll. Geofis. Teor. Appl., 28 (111112), 235-240.

Fedi, M., G. Florio and A. RAPOLla (1990): The role of remanent magnetization in the Southern Italian crust from aeromagnetic anomalies, Terra Nova, 2, 629-637.

Fedi, M., G. Florio and A. Rapolla (1994): The Magnaghi Seamount: a gravimetric and magnetic combined study, Boll. Geofis. Teor. Appl., 36 (141-144), 523-531.

Fedi, M., G. Florio and A. RAPOlla (1998): 2.5D modelling of Somma-Vesuvius structure by aeromagnetic data, J. Volcanol. Geotherm. Res., 82 (1-4), 239-247.

Fedi, M., F. Cella, G. Florio and A. Rapolla (2005): Multiscale derivative analysis of the gravity and magnetic fields of Southern Apennines (Italy), in CROP deep seismic exploration of the Mediterranean Region, edited by I.R. FINETTI (Elsevier), vol. I, 281-318.

Filin, A.M., A.M. GorodnizKJi, N.A. PALShin, K.V. Popov, N.A. SCHISHKINA and A.A. SCHREIDER (1988): New data on structure of field of magnetic anomaly on seamounts Vercelli and Vavilov (Tyrrhenian Sea), Oceanology (Sophia), 17, 58-66 (in Russian).

Florio, G., M. Fedi, F. Cella and A. Rapolla (1999): The Campanian Plain and Phlegraean Fields: structural setting from potential field data, J. Volcanol. Geotherm. Res., 91, 361-379.

Gantar, C., C. Morelli and M. PisAni (1968): Information report on surface gravity and magnetic measurements with the ship «Bannock» in the Mediterranean Sea 1965-1968.5, Boll. Geofis. Teor. Appl., 10, 134-157.

Hutchison, I., R.P. Von HERZEN, K.E. LOUdEN, J.G. SClATER and J. JEMSEK (1985): Heat flow in the Balearic and Tyrrhenian basins, Western Mediterranean, J. Geophys. Res., 90, 685-702.

IACOBUCCI, F., A. InCORONATO, A. Rapolla and S. SCARASCIA (1977): Basement structural trends in the volcanic islands of Vulcano, Lipari and Salina (Eolian Islands, Southern Tyrrhenian Sea) computed by aeromagnetic and gravimetric data, Boll. Geofis. Teor. Appl., 20 (7374), 49-61.

InCORONATO, A. and G. NARDI (1987): Paleomagnetic evidences for a Peri-Tyrrhenian orocline, in The Lithosphere in Italy. Advances in Earth Science Research, edited by A. Boriani, M. Bonafede, G.B. PicCardo and B. VAGG (Ital. Nat. Comm. Int. Lithosphere Progr.), 65-76.

JudENHERC, S. and A. Zollo (2004): The Bay of Naples (Southern Italy): constraints on the volcanic structures inferred from a dense seismic survey, J. Geophys. Res., 110, B06307, doi:10.1029/2005JB003645.

Kastens, K., J. Mascle, C. Auroux, E. Bonatti, C. 
Broglia, J. Channell, P. Curzi, K.C. Emeis, G. Glacon, S. Asegawa, W. Hieke, G. Mascle, F. McCoy, J. McKenzie, J. Mendelson, C. Muller, J.P. RÉHAULT, A. RoBERTSON, R. SARTORI, R. SPROVIERI and M. TORII (1988): ODP Leg 107 in the Tyrrhenian Sea: Insights into passive margin and back-arc basin evolution, Geol. Soc. Am. Bull., 100, 1140-1156.

Kazmin, V.G., N.A. Marova, G.N. Alekhina and N.F. TICHONOVA (1990): Volcanoes of the Tyrrhenian Sea deep water basin, Oceanology, 30 (4), 606-614 (in Russian).

Langel, R.L., C.C. Schnetzler, J.D. Phillips and R.J. HORNER (1982): Initial vector anomaly map from MAGSAT, Geophys. Res. Lett., 9, 250-253.

McKenzie, D. and M.J. BickLe (1988): The volume and composition of melt generated by extension of the lithosphere, J. Petrol., 29, Part 3, 625-679.

Makris, C., C. Morelli and C. Zanolla (1998): The Bouguer Gravity Map of the Mediterranean Sea (IBCM-G), Boll. Geofis. Teor. Appl., 39 (2), 79-98.

MANTOVAni, E., D. BABBUCCI and F. FARSI (1985): Tertiary evolution of the Mediterranean Region: major outstanding problems, Boll. Geofis. Teor. Appl., 27 (105), 67-90.

Marsella, E., G. Aiello, A. Angelino, P.P. Bruno,V. Di Fiore, F. Giordano, N. Pelosi, A. Siniscalchi, C. D'IsANTO and S. RugGIERI (2002): Shallow geological structures and magnetic anomalies in the Gulf of Naples: An integrated analysis of seismic and magnetometric profiles, Boll. Geofis. Teor. Appl., 42 (1-2), 292-297.

Marson, I. and G.F. PANZA (1990): Aeromagnetic map of Italy reduced to the some elevation and to the Pole, Atti Acad. Naz. Lincei, 1, 245-252.

Marson, I., G.F. PanZa and P. SuhadolC (1995): Crust and upper mantle models along the active Tyrrhenian rim, Terra Nova, 7, 348-357.

Morelli, C. (1970): Physiography, gravity and magnetism in the Tyrrhenian Sea, Boll. Geofis. Teor. Appl., 12, 275-305.

Morelli, C., C. Gantar and M. Pisani (1975a): Bathymetry, gravity and magnetism in the Strait of Sicily and in the Ionian Sea, Boll. Geofis. Teor. Appl., 17, 39-58.

Morelli, C., M. PISANi and C. Gantar (1975b): Geophysical anomalies and tectonics in the Western Mediterranean, Boll. Geofis. Teor. Appl., 18, 67, 211-249.

Morelli, C. and S. VAL'CHUK (1988): The International Bathymetric Chart of the Mediterranean (I.B.C.M.) published under the authority of the Intergovernmental Oceanographyc Commission of UNESCO, in IBCM Supporting Volume, edited by J.K. HALL, Jerusalem, Israel, Ch. 1, pp. 10.

NABIGHIAN, M.N. (1984): Toward a three-dimensional automatic interpretation of potential field data via generalized Hilbert transforms: fundamental relations, Geophysics, 49, 780-786.

NAPOLI, R, G. CurRenti and C. Del Negro (2007): Ground magnetic anomaly images of Ustica Island (Italy). Ext. Abstr. from: EGM 2007 International Workshop Innovation in EM, Grav and Mag Methods: a new Perspective for exploration Capri, (Italy, April 15-18, 2007).

Nicolich, R. (1989): Crustal structures from seismic studies in the frame of the European Geotraverse (Southern segment) and CROP projects, in Proceedings of «The lithosphere in Italy», Acc. Naz. Lincei, 80, 41-61.
NunZiATA, C. and A. RAPOlla (1987): A gravity and magnetic study of the volcanic island of Ischia, Naples (Italy), J.Volcanol. Geotherm. Res., 31, 333-344.

Oceanic Drilling Project, Leg 107 Scientific Drilling PARTY (1986): Young Tyrrhenian Sea evolved very quickly, Geotimes, 31, 11-14.

Ogniben, L., M. Parotto and A. Praturlon (Editors) (1975): Structural model of Italy, CNR, Quad. Ric. Sci., 90.

Okuma, S., T. Nakatsuka, M. Komazawa, M. Sugihara, S. NAKANO, R. FuRUKAWA and R. Supper (2006): Shallow subsurface structure of the Vulcano-volcanic complex, Italy, constrained by helicopter-aeromagnetic surveys, Explor. Geophys., 37, 129-138.

ORsi, G., S. DE VitA and M. Di Vito (1996): The restless, resurgent Campi Flegrei nested caldera (Italy): Constraints on its evolution and configuration, J. Volcanol. Geotherm. Res., 74, 179-214.

Paoletti, V., M. Fedi, G. Florio, R. SupPer and A. RapolLA (2004): The new integrated aeromagnetic map of the Phlegrean Fields volcano and surrounding areas, Ann. Geophysics, 47 (5), 1569-1580.

Paoletti, V., R. Supper, M. Chiappini, M. Fedi, G. Florio and A. RAPOLLA (2005a): Aeromagnetic survey of the Somma-Vesuvius volcanic area, Ann. Geophysics, 48 (2), 199-213.

Paoletti, V., R. Di Maio, F. Cella, G. Florio, K. Mocka, N. Roberti, M. Secomandi, R. Supper, M. Fedi and A. RAPOLLa (2009): The Ischia Volcanic Island (Southern Italy): Inferences from Potential Field Data Interpretation, Journal of Volcanology and Geothermal Research, (Elsevier), 179, 69-86.

Paoletti, V., M. Secomandi, M. Fedi, G. Florio and A. RAPOLLA (2005b): The integration of magnetic data in the Neapolitan volcanic district, Geosphere, 1 (2), 85-96.

PinNA, E. and A. RAPOLLA (1979): Strutture crostali nell'Italia Meridionale da dati gravimetrici, in Proceedings of Catania Seminar, Geodynamic Special Project, edited by G. Luong, Pubbl. n. 235 (Progetto Finalizzato Geodinamica, CNR).

Rapolla, A., M. Fedi and G. Fiume (1989): Crustal structure of the Ischia-Phlegraean geothermal fields, near Naples, Italy, from gravity and aeromagnetic data, Geophys. J., 97, 409-419.

RecQ, M., J.P. Rehault, L. Steinmetz and A. Fabbri (1984): Amincissement de la croute et accretion au centre du Bassin Tyrrehenien d'apres la sismique refraction, Mar. Geol., 55, 411-428.

Rehault, J.P., J. Maskle, A. Fabbri, F. Moussat and M. Thommeret (1987): The Tyrrhenian Sea before LEG 107, in Proc. ODP, Init. Repts., College Stations, TX, Ocean Drilling Program, edited by K.A. KASTENS et al., 107, 5-35.

Scarascia, S., A. LozeJ and R. Cassinis (1994): Crustal structures of the Ligurian, Tyrrhenian and Ionian Seas and adjacent onshore areas interpreted from wide-angle seismic profiles, Boll. Geofis. Teor. Appl., XXXVI (141-144), 5-19.

Secomandi, M., V. Paoletti, G. Aiello, M. Fedi, E. Marsella, S. Ruggieri, B. D'Argenio and A. RapolLA (2005): Analysis of the magnetic anomaly field of the volcanic district of the Bay of Naples, Italy, Mar. Geophys. Res., 24 (3-4), 207-221. 
SELLI, R. (1981): Thoughts on the geology of the Mediterranean region, in Sedimentary Basins of Mediterranean Margins, Italian Project of Oceanography, edited by F.C. WEZEL (Tecnoprint, Bologna), 489-501.

Smirnov, A.V., G.A. Stefanov, V.A. Sichev, I.V. TuMANOVAND and A.A. SCHREIDER (1980): Near bottom Geophysical study of the Palinuro Seamount, Oceanology, 6, 1113-1117 (in Russian).

SuPPER, R., R. De Ritis, K. MOTSCHKa and M. CHIAPPINI (2004): Aeromagnetic anomaly images of Vulcano and Southern Lipari Islands (Aeolian Archipelago, Italy), Ann. Geophys., 47 (6), 1803-1810.

Steinmetz, L., F. Ferrucci, A. Hirn, C. Morelli and R. Nicolich (1983): A $550 \mathrm{~km}$ long Moho traverse in the Tyrrhenian Dea from O.B.S. recorded $P n$ waves, Geophys. Res. Lett., 10, 428-431.

SuHADOLC, P. and G.F. PANZA (1989): Physical properties of the lithosphere-asthenosphere system in Europe from geophysical data, in Proceedings of «The lithosphere in Italy», Acc. Naz. Lincei, 80, 15-40.

USGS (1965): Report of the Cruise C-12-65-MS (0912) carried out by Lamont-Doherty Earth Observatory (available on line <http://walrus.wr.usgs.gov/infobank/c/c1265ms/ $\mathrm{html} / \mathrm{c}-12-65-\mathrm{ms} . \mathrm{meta} \cdot \mathrm{html}>$ ).

Zito, G., F. Mongelli, S. De Lorenzo and C. Doglioni (2003): Geodynamical interpretation of the heat flow in the Tyrrhenian Sea, Terra Nova, 15, 425-432.

WANG, C.Y., W.T. AwaNG and S. YAolin (1989): Thermal evolution of a rift basin: the Tyrrhenian Sea, J. Geophys. Res., 94 (B4), 3991-4006.

WASILEWSKY, P.J. and M.A. MAYHew (1982): Crustal xenolith magnetic properties and long wavelength anomaly source requirements, Geophys. Res. Lett., 9 , 329-332. 